\title{
Development and Testing of Thrombolytics in Stroke
}

\author{
Dmitri Nikitin, ${ }^{\text {ab,** }}$ Seungbum Choi, ${ }^{\mathrm{c}, *}$ Jan Mican, ${ }^{\mathrm{a}, \mathrm{b}, \mathrm{d}}$ Martin Toul, ${ }^{\mathrm{a}, \mathrm{b}}$ Wi-Sun Ryu, ${ }^{\mathrm{e}}$ Jiri Damborsky, ${ }^{\mathrm{a}, \mathrm{b}}$ \\ Robert Mikulik, ${ }^{\mathrm{a}, \mathrm{d}}$ Dong-Eog Kim ${ }^{\mathrm{c}, \mathrm{e}}$ \\ IInternational Centre for Clinical Research, St. Anne's Hospital, Brno, Czech Republic \\ 'Loschmidt Laboratories, Department of Experimental Biology and RECETOX, Faculty of Science, Masaryk University, Brno, Czech Republic \\ 'Molecular Imaging and Neurovascular Research Laboratory, Department of Neurology, Dongguk University College of Medicine, Goyang, Korea \\ 'Department of Neurology, St. Anne's Hospital and Faculty of Medicine, Masaryk University, Brno, Czech Republic \\ 'Department of Neurology, Dongguk University llsan Hospital, Goyang, Korea
}

Despite recent advances in recanalization therapy, mechanical thrombectomy will never be a treatment for every ischemic stroke because access to mechanical thrombectomy is still limited in many countries. Moreover, many ischemic strokes are caused by occlusion of cerebral arteries that cannot be reached by intra-arterial catheters. Reperfusion using thrombolytic agents will therefore remain an important therapy for hyperacute ischemic stroke. However, thrombolytic drugs have shown limited efficacy and notable hemorrhagic complication rates, leaving room for improvement. A comprehensive understanding of basic and clinical research pipelines as well as the current status of thrombolytic therapy will help facilitate the development of new thrombolytics. Compared with alteplase, an ideal thrombolytic agent is expected to provide faster reperfusion in more patients; prevent re-occlusions; have higher fibrin specificity for selective activation of clot-bound plasminogen to decrease bleeding complications; be retained in the blood for a longer time to minimize dosage and allow administration as a single bolus; be more resistant to inhibitors; and be less antigenic for repetitive usage. Here, we review the currently available thrombolytics, strategies for the development of new clot-dissolving substances, and the assessment of thrombolytic efficacies in vitro and in vivo.

Keywords Stroke; Thrombolytic therapy; Tissue plasminogen activator; Protein engineering
Correspondence: Dong-Eog Kim Molecular Imaging and Neurovascular Research Laboratory, Department of Neurology, Dongguk University College of Medicine, 27 Dongguk-ro, Ilsandong-gu, Goyang 10326, Korea

Tel: +82-31-961-7211

Fax: +82-31-961-7212

E-mail: kdongeog@duih.org https://orcid.org/0000-0002-93396539

Co-correspondence: Robert Mikulik International Centre for Clinical Research, St. Anne's Hospital, Pekařská 53, 62500 Brno, Czech Republic

Tel: +420-543-1826-46

Fax: +420-543-1826-21

E-mail: robert.mikulik@fnusa.cz https://orcid.org/0000-0002-74585166

Co-correspondence: Jiri Damborsky Loschmidt Laboratories, Department of Experimental Biology and RECETOX, Faculty of Science, Masaryk University, Kamenice 5/A13, 62500 Brno, Czech Republic

Tel: +420-549-4930-41

Fax: +420-549-4962-03

E-mail: jiri@chemi.muni.cz https://orcid.org/0000-0002-78488216

Received: August 10, 2020 Revised: September 9, 2020 Accepted: September 28, 2020

*These authors contributed equally to the manuscript as first author.

\section{Introduction}

Stroke is one of the leading causes of death and disability world- wide. It is also one of the most frequent causes of dementia and epilepsy. Moreover, the incidence of stroke will be increasing because of population aging. ${ }^{1}$ The impact of stroke on modern so- 
cieties is and will be enormous because of loss of lives, loss of quality of life of surviving patients and their families, and its huge socioeconomic burden.

Until 2014, the only evidence-based therapy to reverse the neurological deficit in acute ischemic stroke was the administration of intravenous tissue plasminogen activator (tPA) within 4.5 hours from symptom onset. ${ }^{2}$ Since 2015, several studies have demonstrated the substantial benefits of mechanical thrombectomy in patients with acute stroke due to large vessel occlusion. ${ }^{3-5}$ Despite the advances in recanalization therapy, approximately half of patients with severe ischemic stroke remain disabled or die. ${ }^{3-5}$ Moreover, access to mechanical thrombectomy is quite limited in many countries owing to lack of resources or experts. ${ }^{6}$ Furthermore, mechanical thrombectomy will never be a treatment for every ischemic stroke because many of them are caused by occlusion of cerebral arteries that cannot be reached by intra-arterial catheters.

To address these needs, various non-interventional treatments are being developed, as described recently. ${ }^{7}$ Thrombolytics, compared with other treatments, appear to hold greater promise for stroke management since they have already demonstrated clinically proven therapeutic utility. However, thrombolytics have shown relatively limited efficacy and notable hemorrhagic complication rates, leaving room for improvement. In this article, we summarize the currently available thrombolytics, including their advantages and shortcomings, and describe strategies for developing and testing principally new thrombolytics in pre-clinical and clinical settings. A comprehensive understanding of basic and clinical research pipelines and the current status of thrombolytic therapy will help facilitate the development of new thrombolytics.

\section{Current thrombolytics}

\section{Tissue plasminogen activator}

\section{Molecular structure of tPA}

tPA was discovered in animal tissues in 1947 and successfully purified in $1979 .{ }^{8}$ tPA is synthesized as a single-chain protein, but can be converted into a two-chain form by plasmin or kallikreins without loss of fibrinolytic efficiency. ${ }^{9}$ It is secreted by vascular endothelial cells, glial cells, and neurons. ${ }^{10-12}$ tPA consists of five functional domains (Figure 1): (1) a fibronectin-like or finger domain ( $F_{1} 4-50$ amino acids $\left.[A A]\right),(2)$ an epidermal growth factor (EGF)-like domain (E, 50-87 AA), (3) a kringle 1 domain (K1, 87-176 AA), (4) a kringle 2 domain (K2, 176-256 $A A)$, and (5) a catalytic serine protease domain ( $P, 276-527$ AA). ${ }^{13}$ tPA binds to fibrin through its $F, K 2$, and probably, K1 do- mains, while its $\mathrm{F}$ and $\mathrm{E}$ domains are responsible for a fast clearance by hepatocytes. ${ }^{14,15}$ The average half-life of tPA in plasma is approximately 6 minutes. ${ }^{16}$ Carbohydrate chains, which are connected to tPA via three $\mathrm{N}$-glycosylation sites at residues 117 , 184, and 448, and one 0-fucosylation site at Thr61, influence the clearance efficiency and plasma half-life. ${ }^{17,18}$

\section{Biological function of $t P A$}

tPA is a serine protease that converts plasminogen into active plasmin, which can degrade fibrin clots. ${ }^{19}$ Moreover, it also regulates many other physiological processes, such as neuronal migration, neurite outgrowth, glutamatergic neurotransmission, long-term potentiation, synaptic plasticity, and neurovascular coupling. ${ }^{20-26}$

\section{Clinical use of tPA}

Clinical research has mostly revolved around alteplase, a recombinant form of tPA, which is still the only Food and Drug Administration (FDA)-approved thrombolytic drug for the treatment of acute ischemic stroke. It was approved by the FDA for the management of acute myocardial infarction in 1987, acute massive pulmonary embolism in 1990, and acute ischemic stroke in 1996. ${ }^{27}$ In a meta-analysis of individual patient data from 6,756 patients in nine randomized trials comparing with a placebo or open control, alteplase significantly increased the odds of a good outcome when given within 4.5 hours after ischemic stroke. There was an absolute increase of approximately $2 \%$ in the risk of early death caused by intracranial hemorrhage, although it was offset by an increase in disability-free survival. The rates of alteplase-mediated recanalization can be as low as 5\% to 10\% for proximal large vessel occlusion, although they are much higher for more distal occlusions. ${ }^{28}$

\section{Protein engineering of alteplase}

Many attempts have been made to improve biochemical properties of alteplase by protein engineering to construct different variants, for example, monteplase (with a mutation Cys84Ser in the EGF domain), ${ }^{29}$ lanoteplase (with a mutation Asn 117GIn in the $\mathrm{K} 1$ domain), ${ }^{30}$ pamiteplase (with $\mathrm{K} 1$ domain deleted and a mutation Arg275Glu), ${ }_{1}^{31}$ and amediplase (with $\mathrm{K} 2$ domain from tPA and $\mathrm{P}$ domain from urokinase). ${ }^{32} \mathrm{~A}$ detailed description of the domains is presented in Figure $1 .{ }^{33-36}$ All these drugs have prolonged plasma half-life but decreased fibrin specificities. In contrast, tenecteplase (TNK), which is generated by a few point mutations, has a longer plasma half-life and a 14-fold higher fibrin specificity owing to the substitution of Thr103Asn (introducing glycosylation site), Asn117GIn (deleting glycosylation site), and Lys296-His297-Arg298-Arg299 with four alanines. ${ }^{37}$ 

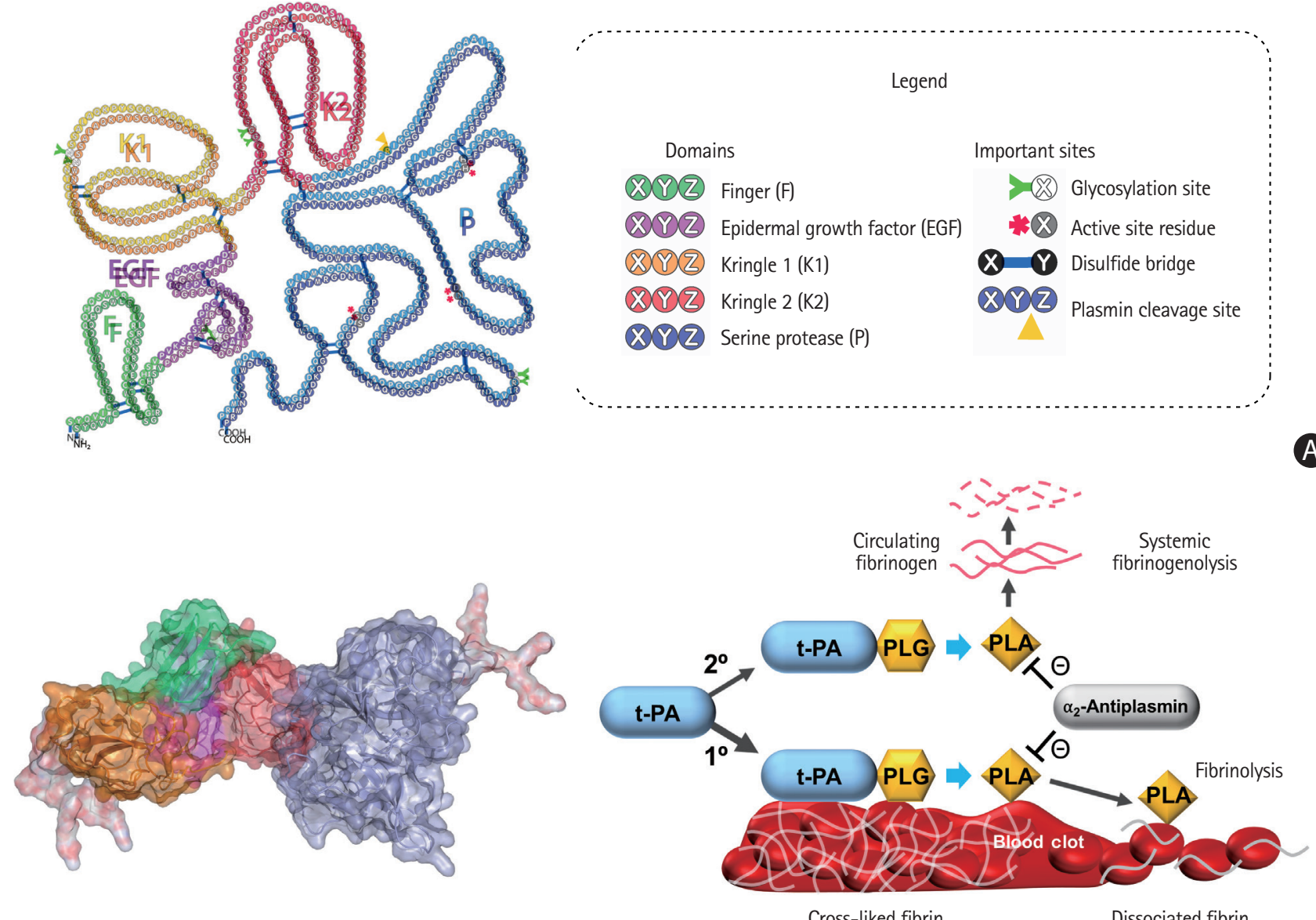

B

Figure 1. Molecular structure and fibrinolytic function of tissue plasminogen activator (tPA). (A) The F domain (green) is involved in binding to fibrin, which stimulates the activity of tPA. Binding of F and epidermal growth factor (EGF)-domain (violet) to the low-density lipoprotein receptor-related protein 1 (LRP1) receptor on the surface of a hepatocyte is involved in the clearance of TPA. The K1 domain (orange) is homologous to the K domains of urokinase and desmoteplase, and glycosylation at Asn117 on the K1 domain influences tPA uptake in the liver. ${ }^{34}$ The K2 domain (red) has a lysine-binding site, which binds to partially degraded fibrin and other proteins containing C-terminal lysines. This could be the basis of enhancement of plasminogen activating activity of tPA by interacting with cofactors other than fibrin. The trypsin-like serine protease P domain (steelblue) is responsible for the catalytic activity of tPA. Upon tPA binding to fibrin, the catalytic activity is increased by both colocalization of plasminogen and conformational change of tPA into a more active state. (B) Carbohydrate chains (white+red) affect the half-life of tPA by interacting with the mannose receptor and asialoglycoprotein receptor on the endothelial cells in the liver. ${ }^{33,35}$ In addition, carbohydrate chains influence the catalytic activity by preventing interactions between the domains of tPA. ${ }^{35}$ (C) The cartoon in the lower right panel illustrates the mechanism of tPA-mediated fibrinolysis in thrombi and circulating blood. Fibrinolysis $\left(1^{\circ}\right)$ occurs after tPA binds to fibrin-associated plasminogen (PLG) on the surface of the clot by generating plasmin (PLA), and thereby breaking the cross-links between fibrin molecules. PLA could also break down circulating fibrinogen $\left(2^{\circ}\right)$, and thus potentially causing bleeding complications. Plasmin activity is inhibited by $\mathrm{a}_{2}$-antiplasmin. Images of molecular structures of tPA that were adapted from Mican et al. ${ }_{1}^{36}$ with permission from the Elsevier.

The latter substitutions decrease plasminogen activator inhibitor 1 (PAI-1) inhibition up to 80 -fold. ${ }^{37}$ Clinical trials with TNK have revealed a decrease in bleeding complications. ${ }^{38}$

\section{Urokinase}

Urokinase was discovered in human urine in $1947 .^{39}$ It is produced by vascular endothelial cells, smooth muscle cells, epithelial cells, fibroblasts, monocytes/macrophages, and various types of cancer cells..$^{40-44}$ The enzyme is involved in a variety of physiological processes, such as cell migration, tissue remodeling, complement activation, pro-hormone conversion, and wound healing. ${ }^{45}$ Urokinase is a serine protease, which consists of three domains: (1) an EGF-like domain ( $E, 1-49 A A),(2)$ a kringle domain ( $K, 50-131 \mathrm{AA})$; and (3) a catalytic serine protease domain ( $P, 159-411$ AA) with a catalytic triad His204, Asp255, and Ser356. ${ }^{46}$ Urokinase is cheaper than alteplase and widely used for the treatment of ischemic stroke in developing countries. ${ }^{47}$ In developed countries, urokinase is clinically used 
for treating deep venous thrombosis and peripheral arterial occlusive disease. Urokinase was approved by the FDA for the systemic treatment of pulmonary embolism ${ }^{48}$ and catheter-directed treatment of acute myocardial infarction. ${ }^{49,50}$

\section{Streptokinase}

Streptokinase was discovered in $\beta$-hemolytic streptococci in 1933. ${ }^{51}$ This indirect plasminogen activator is naturally involved in the propagation of streptococcal infections via the breakdown of restraining fibrin barriers. ${ }^{52}$ It is approved by the FDA for acute myocardial infarction, pulmonary embolism, deep vein thrombosis, and arterial thrombosis treatments.

\section{Staphylokinase}

As another indirect plasminogen activator of bacterial origin, staphylokinase is secreted by lysogenic Staphylococcus aureus. ${ }^{53}$ This protein generates plasmin only on the fibrin clot surface because of the rapid inhibition of free plasmin by its inhibitor $\mathrm{a}_{2}$-antiplasmin. ${ }^{54}$ Staphylokinase also prefers conformation of the fibrin-bound plasminogen: only a small percentage associates with free molecules, but the main fraction strongly interacts with the fibrin-bound ones. ${ }^{55}$ These features help prevent bleeding complications. Successful clinical application of staphylokinase for thrombolysis has been confirmed by the Collaborative Angiographic Patency Trial of Recombinant Staphylokinase (CAPTORS) I and II trials in patients with acute ST-elevation myocardial infarction. ${ }^{56,57}$

\section{Desmoteplase}

Blood-sucking animals are a useful source of naturally evolved plasminogen activators. Desmoteplase, a $50 \mathrm{kDa}$ serine protease, was discovered in the saliva of the vampire bat Desmodus rotundus in $1974 .^{58}$ Desmoteplase consists of four functional domains: (1) a fibronectin-like or finger domain (F), (2) an EGFlike domain (E), (3) a kringle 1 domain (K1), and (4) a catalytic serine protease domain (P). The last one contains three catalytic AAs involved in the proteolysis: His237, Asp296, and Ser393. ${ }^{59}$ Desmoteplase adopts an open conformation upon binding to fibrin via the $\mathrm{F}$ domain, which increases its plasmin generating activity approximately 100,000-folds, the highest value among all thrombolytics discovered so far. ${ }^{60}$ Substitution of the alteplase F-domain with the corresponding domain of desmoteplase and the removal of the K2 domain increased the affinity to fibrin by 1.2-fold and provided fibrin stimulatory effect of up to 1,560 times. ${ }^{61}$ A similar F-domain replacement and deletion of the lysine binding site of the K2 domain resulted in a 1.2-fold greater affinity to fibrin and a 14-fold higher fibrin stimulatory effect. ${ }^{61,62}$ Clinical trials, such as Desmoteplase in
Acute Ischemic Stroke (DIAS) ${ }^{63}$ and Dose Escalation of Desmoteplase in Acute Ischemic Stroke (DEDAS), have revealed that desmoteplase has high recanalization (up to $53.3 \%$ in patients treated with $125 \mu \mathrm{g} / \mathrm{kg}$ desmoteplase) and low intracranial hemorrhage (0\%) rates. ${ }^{64}$ DIAS-2 and DIAS-3 trials have confirmed that it is a safe thrombolytic drug. ${ }^{65}$

\section{Development of novel thrombolytics}

\section{Characteristics of "ideal" thrombolytics}

Enzymatic thrombolysis has revolutionized the therapy of cardiovascular and cerebrovascular diseases; early treatment (1) restores blood flow in the occluded vessels, (2) reduces the damage of surrounding tissues, and thus (3) increases survival rates. ${ }^{46}$ The "ideal" thrombolytic drugs should (1) provide fast reperfusion in all patients, (2) prevent reocclusions, (3) have high fibrin specificity for selective activation of clot-bound plasminogen to decrease bleeding complications, (4) be retained in the blood for a long time to minimize dosage and allow administration as a single bolus vs. continuous infusion, (5) be resistant to inhibitors, and (6) be non-antigenic for repetitive usage. ${ }^{66}$

\section{Shortcomings of current thrombolytics}

Current FDA-approved thrombolytic drugs, such as streptokinase, urokinase, and alteplase, have several limitations, restricting the overall success rates of the treatments. Streptokinase has low fibrin specificity and causes an immune response in host organisms. Urokinase degrades not only fibrin clots but also fibrinogen and other plasma proteins, leading to systemic fibrinolysis and increased rates of bleeding complications. ${ }^{47} \mathrm{Ow}-$ ing to low fibrin specificity, urokinase is not used for thrombolysis in stroke treatments. Instead, it is widely used for thromboIytic therapy of deep venous thrombosis, peripheral arterial occlusive disease, and pulmonary embolism, ${ }^{48,67,68}$ as described previously. It was also found to be effective for the restoration of patency in intravenous catheters occluded by clotted blood. ${ }^{69}$

Alteplase has a short plasma half-life (approximately $6 \mathrm{~min}$ utes), but it was shown to be effectively (approximately 550fold) stimulated by fibrin. ${ }^{70}$ In fibrin-bound plasminogen, the target peptide bond becomes available because of conformational changes after lysine-dependent binding to fibrin. ${ }^{71}$ These mechanisms make alteplase a safer thrombolytic drug in comparison with streptokinase and urokinase. Thus, it has a wider spectrum of FDA-approved clinical applications: it is used for the treatment of ischemic stroke, acute myocardial infarction, and pulmonary embolism. ${ }^{27,72}$ However, in ischemic stroke trials the recanalization rate following alteplase administration was $<10 \%$ within 1 hour, $<35 \%$ within 2 hours, and $<43 \%$ within 
24 hours. $^{73-75}$ In approximately 3\% to 6\% of patients, alteplase treatments have led to intracerebral hemorrhage (ICH). ${ }^{76,77}$ The major predictive factors for alteplase failure were a bigger thrombus size, poor collaterals, a proximal location of thrombus, or prolonged time to treatment. ${ }^{78-80}$ In patients with acute ischemic stroke due to the middle cerebral artery (MCA) occlusion, intravenous alteplase was shown to recanalize the artery when the length of thrombus did not exceed $8 \mathrm{~mm}^{79}$ The recanalization rate following alteplase treatment for thrombi with a distal location, e.g., distal M1 MCA was approximately 4.5 times higher than for those located at the internal carotid artery (46.4\% and $10.9 \%$, respectively). ${ }^{80}$

\section{Methods for developing novel thrombolytics}

Many strategies are used to develop novel drugs that lack the aforementioned shortcomings of currently used thrombolytic agents (Figure 2). The well-traveled path of finding molecules with thrombolytic activity in different organisms was followed by molecular biology methods to facilitate their discovery, such as construction of fusion proteins or substitution mutagenesis. Computational methods have been widely used in recent years.

\section{Discovery of new molecules}

Many enzymes and small molecules found in nature have thrombolytic activity. Several thrombolytics have been developed by the identification and characterization of molecules found in bacteria, such as the fibrin-specific thrombolytics from Streptococcus uberis, ${ }^{81}$ Bacillus, $^{82}$ or Stenotrophomonas. ${ }^{83}$ A significant effort is invested into nattokinase-a thrombolytic agent originating from Bacillus subtilis found in the fermented soybean food natto. ${ }^{84}$ Other sources of thrombolytics are various eukaryotes, such as the Chlorella alga, ${ }^{85}$ venomous snakes, ${ }^{86,87}$ and polychaetes. ${ }^{88}$ Thrombolytics of non-mammal origin are often direct fibrinolytics that cleave fibrin directly instead of activating plasminogen. The discovery of new thrombolytics can greatly benefit from next-generation sequencing technologies and gene-mining software tools. ${ }^{89}$ Small molecules such as triprenyl phenolic compounds from the Stachybotrys mold promote the binding of plasminogen to fibrin and induce a conformational change in plasminogen, which promotes its activation and thus fibrinolysis. ${ }^{90}$

\section{Domain deletion}

As mentioned before, alteplase is a protein with five exons coding for the domains of different functions. ${ }^{91}$ Besides fibrinolysis, these domains are associated with neurological side effects such as blood-brain barrier dysfunction, $\mathrm{N}$-methyl-D-aspartate receptor (NMDAR)-mediated neurotoxicity, and other neurological
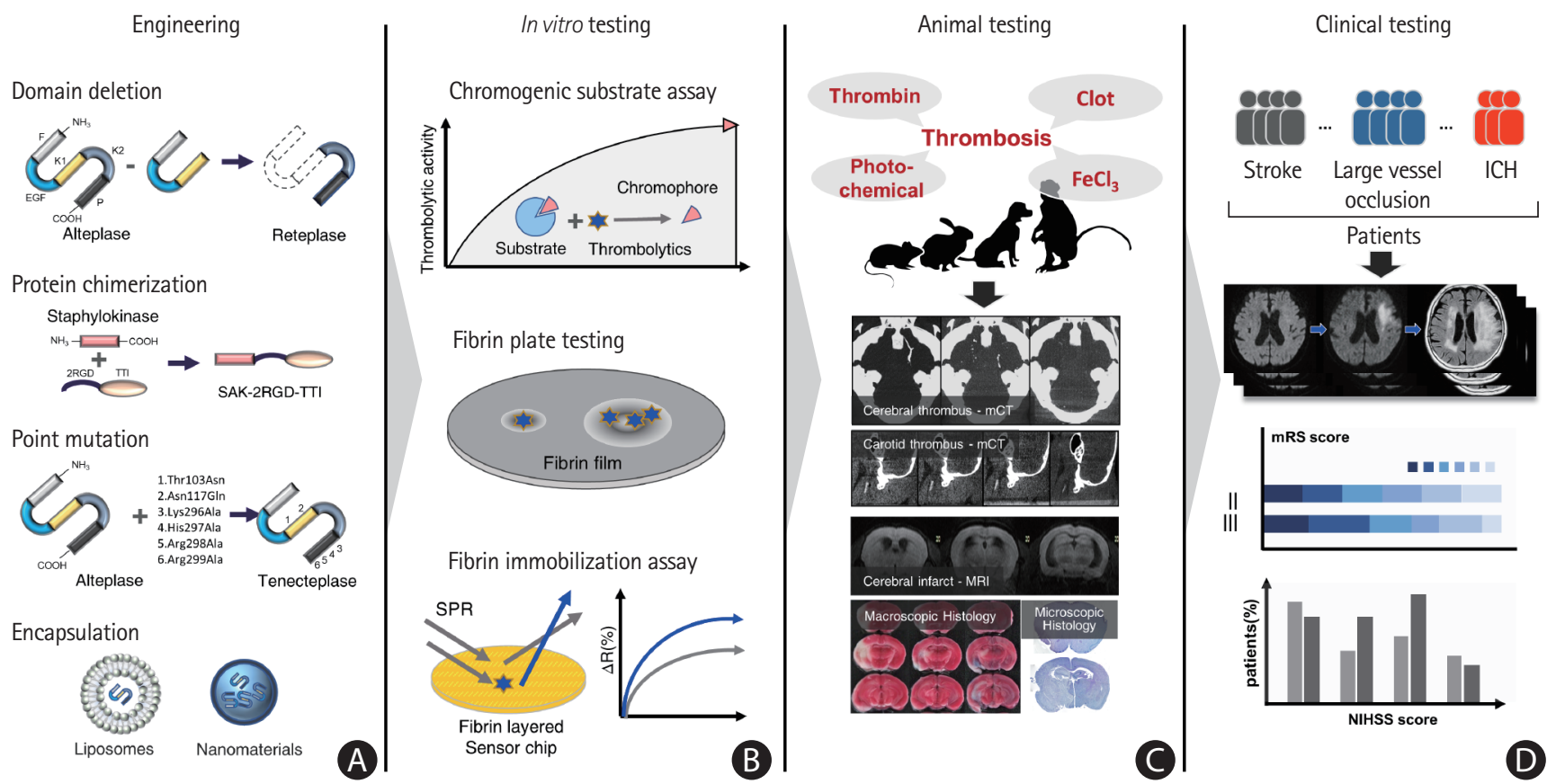

Figure 2. Scheme depicting the development of novel thrombolytics. The overall workflow is separated into four main steps, which are thoroughly discussed in the main text. (A) Development of novel molecules using protein engineering. (B) In vitro testing by biochemical assays. (C) In vivo testing in animal models. (D) Several phases of clinical testing. $F$, finger domain; EGF, epidermal growth factor-like domain; K1, kringle 1 domain; K2, kringle 2 domain; $P$, protease domain; RGD, arginine (R), glycine (G), aspartic acid (D); TI, tsetse thrombin inhibitor; SAK, staphylokinase; SPR, surface plasmon resonance; mCT, micro computed tomography; MRI, magnetic resonance imaging; ICH, intracerebral hemorrhage; mRS, modified Rankin Scale; NIHSS, National Institutes of Health Stroke Scale. 
functions. ${ }^{92-94}$ The first three domains interact with the mannose receptor and low-density lipoprotein receptor-related protein 1 , which are related to TPA clearance by endothelial cells and hepatocytes, respectively. ${ }^{33,95,96}$ Reteplase, a deletion mutant of alteplase, lacks the finger, EGF-like, and kringle 1 domains. It has a long half-life of 15 minutes owing to the absence of the domains responsible for receptor-mediated clearance. Compared with alteplase, reteplase has lower fibrin-binding and better clot penetrability, which leads to faster and more uniform thrombolysis and fewer reocclusions. Owing to the lack of glycosylation and fewer disulfide bridges, reteplase can be expressed at a lower cost using a prokaryotic system. ${ }^{97}$

\section{Protein chimerization}

In contrast to avoiding unwanted functions by the aforementioned domain deletions, constructing chimeric proteins by fusing different proteins or their domains can couple more functions within a single protein. Fibrin-specificity can be achieved through the fusion of EGF domains of thrombomodulin or the K2 domain of alteplase on streptokinase. ${ }^{98,99} \mathrm{~A}$ drug such as staphylokinase can become both thrombolytic and anticoagulative through the fusion of the arginine-glycine-aspartate tripeptide motif, hirudin, annexin $\mathrm{Xl}$, or the tsetse thrombin inhibitor. ${ }^{100-103}$ Fusion of the fibrin-binding kringle 1 domain of plasminogen on staphylokinase increased fibrinolytic effectivity. ${ }^{104}$ Fusion of the Gly-His-Arg-Pro (GHRP) peptide that has a binding affinity for fibrinogen enhanced the fibrin affinity of alteplase. ${ }^{105,106}$ In addition, greater fibrin specificity was achieved by substituting the fibrin-binding fibronectin-like domain of alteplase with the analogous domain of desmoteplase. ${ }^{61}$ Another interesting approach is the fusion of microplasmin and the activation-specific anti-glycoprotein Ilb/Illa antibody. In this way, fibrinolysis by microplasmin is targeted to the clot. Microplasmin is far less inhibited by $\alpha_{2}$-antiplasmin than plasmin in the blood. ${ }^{107}$

\section{Point mutations}

The very short half-life of streptokinase can be extended up to 21-fold by substituting specific charged residues responsible for its proteolysis or by PEGylation (the process of attaching polyethylene glycol [PEG] polymer to molecules). ${ }^{108-110}$ Staphylokinase can be induced to have reduced immunogenicity (30\%) or improved fibrinolytic effectivity by substituting only a few specific residues and using PEGylation. ${ }^{111}{ }^{112}$ Alteplase can be made resistant to PAI- 1 by mutating four charged residues in the catalytic domain to alanine. This mutation, combined with two more substitutions to alleviate low-density lipoprotein-like receptor 1-mediated clearance, provides TNK, which has a 4-fold increased half-life, with more resistance to PAI-1 and higher fi- brin specificity compared with alteplase. These properties make TNK a promising new thrombolytic drug for treating ischemic stroke. ${ }^{113}$ Single point mutations have been introduced in TPA to attenuate its NMDAR-mediated neurotoxicity. ${ }^{114}$ Others showed that alteplase can be made 28 -fold more fibrin specific by substituting the plasmin-sensitive cleavage site with that of desmoteplase. ${ }^{60}$ Recently, Goulay et al..$^{115}$ engineered a variant of tPA devoid of its interaction with the NMDAR by substituting tryptophan 253 in the kringle 2 domain with arginine. They also introduced another point mutation to reduce tPA sensitivity to plasmin without affecting its fibrinolytic activity: a substitution of arginine 275 with serine. In a rat model of ICH and catheter-delivered in situ thrombolysis for the drainage of ICH, the variant tPA reduced hematoma volume. Furthermore, unlike alteplase, the mutant TPA also reduced peri-hematomal neuronal death and edema progression, probably due to the lack of promotion of NMDA-dependent neurotoxicity. ${ }^{115}$ Urokinase became fibrin-specific with fewer bleeding complications by introducing point mutations. ${ }^{116}$

\section{Liposomes and encapsulation}

Encapsulation of thrombolytics in liposomes or other nanomaterials offers interesting opportunities for improving thromboIytic therapy. Liposomes are spherical particles delimited by a lipid bilayer, with a size ranging from $30 \mathrm{~nm}$ to several micrometers. Inside the bilayer-delimited sphere, there is an aqueous phase in which therapeutic molecules, including thrombolytics, can be encapsulated. Other encapsulation techniques are used: encapsulation in blood cell-derived membranes or polymer-based nanoparticles.

Encapsulation in liposomes can significantly improve the half-life of thrombolytics by preventing interactions with clearance receptors in the bloodstream. It also limits systemic plasminemia by preventing the interaction of encapsulated thrombolytics with plasminogen not located in the thrombus. ${ }^{117}$ The half-life and binding properties can be gradually tuned by engineering the composition of liposomes by altering the ratio of different phospholipids in their bilayer, coating them with ligands, or performing PEGylation. ${ }^{118}$

The half-life of liposomal streptokinase is 16-fold longer. ${ }^{117}$ The half-life of tPA was prolonged 21-fold by encapsulation in liposomes. ${ }^{119}$ Besides increasing the half-life, liposomes can also provide other useful pharmacokinetic properties. The accumulation of PEGylated liposomes occurred in two different therapeutic windows of 0.5 and 48 hours after stroke. ${ }^{120}$ The accumulation of liposomes occurred through transcellular transport during the first window and trans- and para-cellular pathways during the second window. ${ }^{120}$ This could be used to provide tar- 
geted therapeutic action both spatially and temporally.

Liposomes themselves prevent immunogenicity and have anti-inflammatory properties. These properties are even more pronounced when they are loaded with anti-inflammatory or neuroprotective agents. ${ }^{121,122}$ Encapsulation of dexamethasone or a combination of tPA and cyclosporine A in liposomes improved neurological scores and reduce subsequent neuroinflammation in rat models of ischemic stroke.

One of the most sought-after properties of liposomes and other nanoformulations is their ability to target thrombolytics to the clot. Liposomes decorated with a fibrinogen-mimicking peptide and loaded with urokinase bind to platelets with high specificity. ${ }^{123}$ Urokinase encapsulated in liposomes decorated with this peptide produced a thrombolytic effect in a rat mesenteric thrombosis model with only $25 \%$ of the dose of free urokinase, and showed significantly less prolonged bleeding times than free urokinase. ${ }^{124}$ Targeted liposomes loaded with urokinase showed improved thrombolytic efficacy in a rat embolic stroke model, too. ${ }^{124}$

Thrombolytic action in the clot can also be achieved through targeted release using ultrasound, infrared radiation, temperature, or shear stress-activated liposomes and other nanotherapeutics. ${ }^{117,125-127}$ The use of echogenic liposomes loaded with thrombolytics couples the diagnostic and therapeutic procedures and was shown to enhance thrombolytic potency. ${ }^{117}$ Loading thrombolytics into blood cell membrane-based particles showed improved therapeutic efficacy over free thrombolytics in animal ischemic stroke and thrombosis models, while preserving coagulation profiles and having fewer bleeding complications. ${ }^{128,129}$ Blood cell membrane-based nanoparticles coated with IPA have led to a significantly better neurological score and survival rate, with a practically unchanged coagulation profiles. Although many studies are exploring the encapsulation of thrombolytics in stroke treatment, ${ }^{117,118}$ the translation to clinical practice is still pending.

\section{Rational protein design}

Determination of the crystal structures of thrombolytic enzymes and using them for in silico modeling have led to big leaps in the development of thrombolytic agents. ${ }^{36}$ The knowledge of the structure of staphylokinase has led to the identification of sites for PEGylation that could improve the half-life while preserving the effectivity of staphylokinase. The effect of mutations on streptokinase can be studied and predicted using the crystal structure of streptokinase bound to microplasmin. ${ }^{130}$ The complete structure of alteplase has not been fully elucidated. However, in silico predictions using the low-resolution structures of alteplase could estimate how deleting any domain decreases its catalytic activity or how it is influenced by glycosylation or enhanced by fibrin. ${ }^{35,131}$ Establishing the structure of reteplase by homology modeling based on alteplase led to improvement in the solubility and fibrin affinity of reteplase..$^{132}$

Each candidate thrombolytic agent should be characterized in vitro and in vivo and compared with previous ones. Choosing efficient and effective experimental methods is important for characterization. The choice often poses a tradeoff between the efficiency and thoroughness of testing. A good in vitro testing strategy can screen more molecules and provide a higher chance of finding a good hit, while also testing candidate thrombolytics for many of the biophysical, biochemical, and biological aspects that are required to be a successful thrombolytic agent.

\section{In vitro testing of novel thrombolytics}

In vitro testing of thrombolytics is typically based on the physiological fibrinolytic pathway (Figure 3A); however, individual assays differ in the level of their complexity, analysis time, reproducibility, and the targeted property. ${ }^{133,134}$ Since none of these methods is superior, it is necessary to always choose the most relevant ones for a given purpose. To obtain a complex understanding of the studied thrombolytics, a combination of different methods may need to be used. An overview of the available assays is provided in Table 1 .

\section{Enzymatic activity assays}

Numerous methods for the assessment of the fibrinolytic potential of thrombolytic proteins are available, ranging from the historic radiolabeling ${ }^{70,135-140}$ to more advanced methods, such as the euglobulin lysis assay, clot formation and lysis (CloFAL) assay, and streptokinase-activated lysis time (SALT) assay. ${ }^{141-143}$ Three basic principles are applied in most of the developed assays.

\section{Fibrin plate assay}

The fibrin plate assay relies on the physiological fibrinolytic pathway (Figure 3A). The plates are prepared by mixing melted agarose with plasminogen, thrombin, and fibrinogen. When a thrombolytic agent is added, fibrin dissolution is assessed by measuring the extent of the clear zone. ${ }^{144-147}$ This method uses fibrin as a key component, making the assay more natural than the chromogenic/fluorogenic assay (see below), while still providing robust and reproducible results. In contrast, the fibrin plate assay is more laborious and time-consuming. Moreover, the growth of the zones depends not only on the fibrinolytic activity but also on the diffusibility of the tested thrombolytics. 

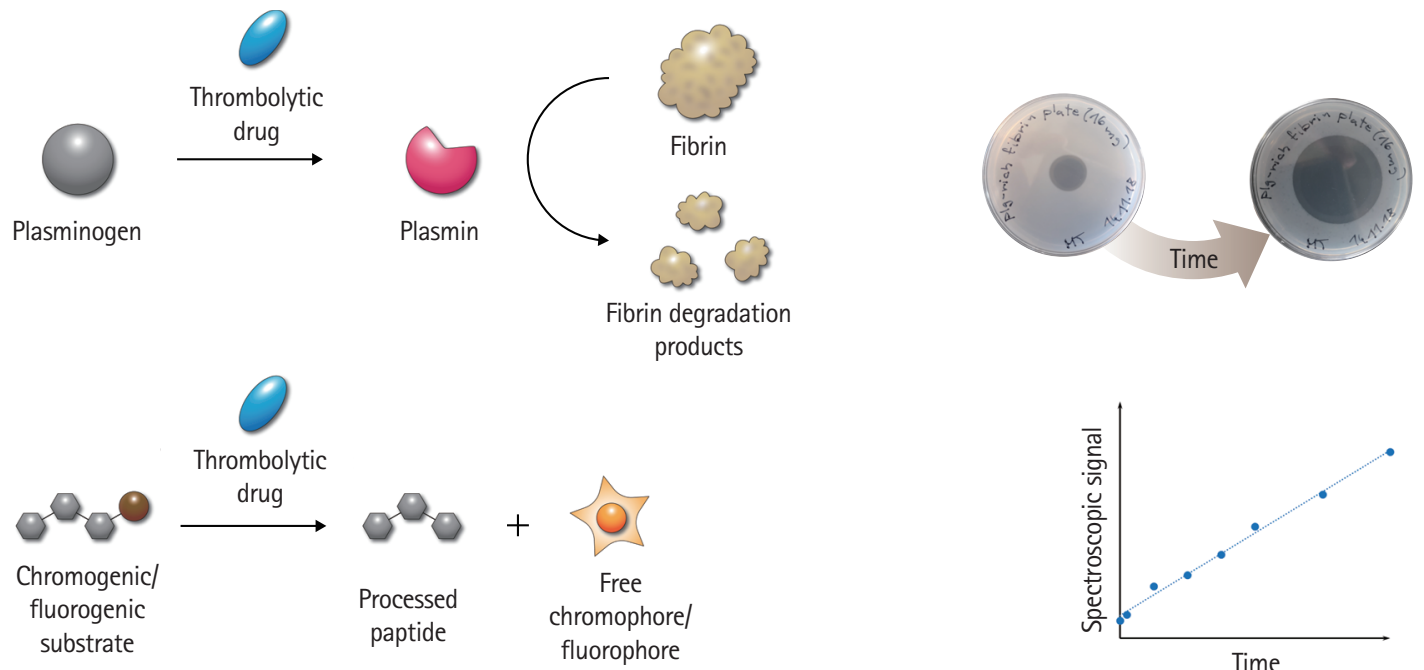

A
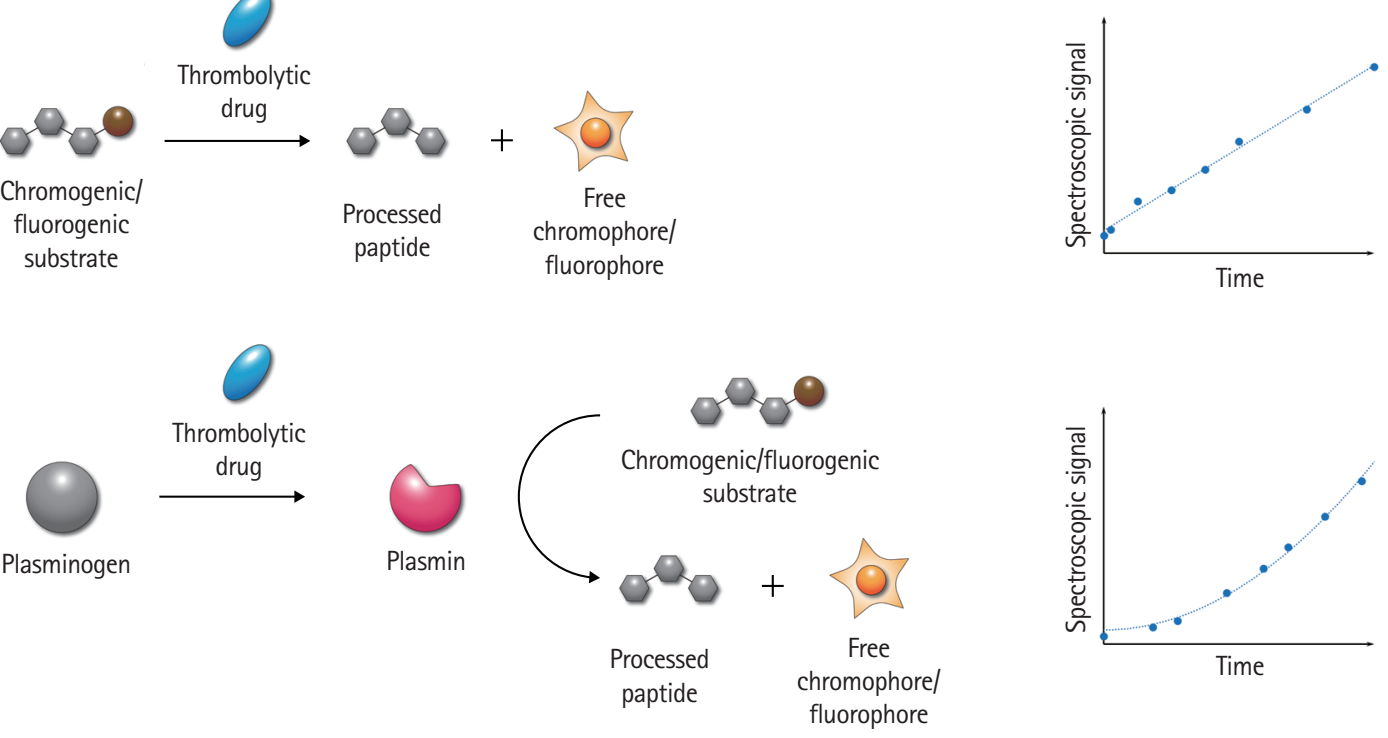

B

Figure 3. Overview of thrombolytic enzymatic activity assays. (A) The physiological thrombolytic pathway without any modification can be monitored by fibrin plates, providing clear zones through the dissolution of fibrin. (B) Direct chromogenic/fluorogenic assay uses a synthetic substrate instead of plasminogen. The assay allows easy and straightforward analysis of thrombolytic enzyme kinetics by a spectrophotometer. The direct cleavage by plasminogen activators results in a linear increase of the signal over time. (C) Coupled chromogenic/fluorogenic assay uses a synthetic substrate instead of fibrin, while the analyzed step of activation involves the physiological plasminogen substrate. The measurement is thus more robust, reliable, and closer to real thrombolytic events than the direct assay. The coupled nature of the assay results in a quadratic increase of the signal over time.

Modified methodologies, such as the dyed fibrin plate assay ${ }^{148}$ and fibrin microplate assay, ${ }_{1}^{149}$ have been developed to resolve some of these problems.

\section{Chromogenic/fluorogenic substrate assay}

This method is based on the cleavage of a synthetic chromogenic or fluorogenic peptide substrate by a thrombolytic enzyme (Figure 3B and C), releasing a free chromophore or a fluorophore and thus generating a measurable spectroscopic signal. ${ }^{150-157}$ The assay is fast, highly reproducible, and depends solely on the activity of the tested enzyme. However, the assay does not use fibrin, a key component influencing thrombolytic activity. To account for the stimulatory effect of fibrin, it is possible to add a small fibrin clot, fibrinogen, or fibrin fragments into the reaction mixture..$^{60,158-161}$ The synthetic substrate can be cleaved directly by plasminogen activators (Figure $3 \mathrm{~B})^{152,155-157}$ or in a coupled arrangement. A thrombolytic drug first activates the natural substrate plasminogen to plasmin, which subsequently processes an analogical chromogenic/fluorogenic substrate (Figure 3C). ${ }^{153,156,157}$ The use of the coupled arrangement makes the analysis more reliable.

\section{Clot lysis assay}

In this assay, macroscopic clots are prepared either by mixing thrombin with plasminogen and fibrinogen, ${ }_{1}^{162,163}$ or clotting human plasma or blood. ${ }^{141-143,164-170}$ Thrombolytics-induced lysis can be roughly monitored visually to report the complete clot Iysis time ${ }^{141,142,162-164}$ or more accurately, by the change in clot-related light scattering. ${ }^{141,143,169,171}$ Other options include measuring (1) the release of red blood cells (RBCs) from whole blood clots, ${ }^{165,166,172,173}$ (2) changes in the clot mass, ${ }^{167,168}$ (3) the viscoelastic properties using thromboelastography, ${ }^{174,175}$ or (4) fluorescence change upon dissolution of labeled clots. ${ }^{176,177} \mathrm{Un}$ like the chromogenic/fluorogenic substrate assay and the fibrin 
Table 1. Comparison of the most common assays used for in vitro testing of thrombolytics

\begin{tabular}{|c|c|c|c|}
\hline Assay & Targeted property & Pros (+) and Cons (-) & Reference \\
\hline Radiolabeling & Activity & $\begin{array}{l}\text { + Direct substrate and product monitoring } \\
\text { - Handling radioactive materials } \\
\text { - Requiring special training and safety equipment }\end{array}$ & 129, 133-138 \\
\hline Fibrin plate assay & Activity & $\begin{array}{l}\text { + More natural than chromogenic and fluorogenic assays (below) } \\
\text { + High reproducibility } \\
\text { - Long and more laborious analysis } \\
\text { - Results influenced by the diffusibility of tested thrombolytics }\end{array}$ & 144-147 \\
\hline Chromogenic/fluorogenic assay & Activity & $\begin{array}{l}\text { + Precise and highly reproducible } \\
+ \text { No interfering factors } \\
\text { + Suitable for kinetic analysis } \\
\text { - Absence of fibrin } \\
\text { - Far from the real fibrinolytic process }\end{array}$ & 60,150-161 \\
\hline Clot lysis assay & Efficiency & $\begin{array}{l}\text { + Most realistic in vitro arrangement } \\
\text { + Presence of real clots, no oversimplification } \\
\text { - Relatively low reproducibility } \\
\text { - Determines only overall thrombolytic efficiency, not individual properties }\end{array}$ & $141-143,162-175,177$ \\
\hline Inhibition resistance assay & Inhibition resistance & $\begin{array}{l}\text { + Fast and easy to perform } \\
\text { - Missing other possibly important factors }\end{array}$ & 178-182 \\
\hline Fibrin immobilization SPR & Fibrin affinity & $\begin{array}{l}\text { + Direct measurement of binding } \\
\text { + Provides both kinetic and equilibrium data } \\
\text { + Suitable for fast screening } \\
\text { - No macroscopic clots present } \\
\text { - Requiring special instrumentation }\end{array}$ & 183-186 \\
\hline Fibrin immobilization ELISA & Fibrin affinity & $\begin{array}{l}\text { + Easy to set up } \\
\text { + Does not require special instrumentation } \\
\text { - No macroscopic clots present } \\
\text { - Lack of information about the kinetics }\end{array}$ & $184,186,187$ \\
\hline Clot binding assay & Fibrin affinity & $\begin{array}{l}\text { + Not requiring specialized equipment } \\
+ \text { Working with macroscopic clots } \\
\text { - Requiring practice in the generation of reproducible clots } \\
\text { - Longer and more laborious analysis }\end{array}$ & 61,188-190 \\
\hline Receptor immobilization SPR & Receptor affinity & $\begin{array}{l}\text { + Direct measurement of binding } \\
+ \text { Provides both kinetic and equilibrium data } \\
+ \text { Suitable for fast screening } \\
\text { - Requiring special instrumentation }\end{array}$ & $95,191,192$ \\
\hline Receptor immobilization ELISA & Receptor affinity & $\begin{array}{l}\text { + Easy to set up } \\
+ \text { Not requiring special instrumentation } \\
\text { - Lack of information about the kinetics }\end{array}$ & 191,193 \\
\hline Receptor binding ITC & Receptor affinity & $\begin{array}{l}\text { + Not requiring immobilization } \\
\text { + Direct measurement without labeling or modification } \\
\text { - Applicable to fully soluble fragments only }\end{array}$ & 194,195 \\
\hline
\end{tabular}

SPR, surface plasmon resonance; ELISA, enzyme-linked immunosorbent assay; ITC, isothermal titration calorimetry.

plate assay, these assays use macroscopic clots, thereby better mimicking in vivo biology. However, a higher level of procedural complexity decreases the accuracy and reproducibility of this assay. In addition, the assays do not solely monitor the enzymatic activity of thrombolytics, but rather their overall effectiveness.

\section{Inhibition resistance assays}

Inhibition resistance assays are performed by incubating thrombolytics with an inhibitor at a predefined concentration for a predefined time. Thereafter, the amount of free and active thrombolytics is determined using enzyme-linked immunosor- bent assay (ELISA) ${ }^{178,179}$ or the chromogenic/fluorogenic assay. ${ }^{178,180-182}$ Such experiments provide information about both the kinetics and thermodynamics of inhibition.

\section{Fibrin affinity assays}

\section{Fibrin immobilization assay}

Fibrin layer or fibrin fragments can be immobilized on sensor chips, and the binding of thrombolytic drugs can be directly analyzed using surface plasmon resonance (SPR). This measurement provides information about both the affinity and the kinetics of the interaction. ${ }^{183-186}$ Alternatively, fibrin can be immo- 
bilized on the surface of a microplate well, incubated with the tested thrombolytic agents, and the amount of bound molecules is determined by using ELISA or the chromogenic/fluorogenic assay. ${ }^{18,186,187}$

\section{Clot binding assay}

To analyze the affinity to macroscopic fibrin clots, fibrinogen is mixed with the tested thrombolytic agents, and clotting is initiated by thrombin. The clot is subsequently sedimented using centrifugation, and the supernatant is used for measuring the amount of unbound thrombolytics using ELISA, the fibrin plate assay, or the chromogenic/fluorogenic assay. ${ }^{61,188-190}$ Although this assay requires thorough optimization to obtain reproducible results, it uses macroscopic clots and does not require any complex instrumentation.

\section{Receptor binding assays}

The affinity of thrombolytics to membrane receptors is typically determined analogically as the affinity to fibrin layers. One option is to analyze binding affinities and kinetics using SPR. ${ }^{95,191,192}$ An alternative approach is to measure the amount of thrombolytics bound to immobilized receptors using specific antibodies (ELISA arrangement) or by the chromogenic/fluorogenic assay after a washing step. ${ }^{191,193}$ In addition, there have been studies reporting affinities to soluble receptor fragments, measured by isothermal titration calorimetry. ${ }^{194,195}$

Overall, in vitro methods are useful for assessing the individual properties affected by structural modifications of a thrombolytic agent. In addition, the assays serve as an important platform for screening large libraries of designed drug variants in a cost-effective, time-efficient, and ethical manner. However, simplifications and deviations from physiological conditions make it essential to further test the safety and efficacy of candidate thrombolytics using in vivo animal models.

\section{In vivo testing of novel thrombolytics}

Thromboembolic stroke models, in which preformed blood clots are injected in arteries, have been generated most often in rodents (rats ${ }^{196-212}$ and mice ${ }^{177,213-219}$ ) and other species including rabbits, ${ }_{1} 200-224 \operatorname{dogs}_{1}{ }^{225,226}$ zebrafish, $^{227}$ and non-human primates. ${ }^{22,229}$ In this section, we summarize the current available thromboembolic stroke models and their advantages and disadvantages in testing thrombolytic agents.

\section{Clot injection-induced thromboembolic stroke model}

Embolic stroke is induced by injecting preformed (autologous or heterologous) blood clots into the MCA-anterior cerebral artery bifurcation area. ${ }^{230-233}$ Despite the relatively high mortality due to invasive surgical procedures, these animal models closely mimic human clots with high variability in the biochemical or cellular composition, and size. ${ }^{234}$

The biochemical and cellular composition can be manipulated by adding fibrin or thrombin to the blood before clotting ${ }^{205}$ or by mixing the blood with RBCs or platelets. ${ }^{235}$ The diameter or length of clots can be controlled by using a clot-forming tube or catheter in various diameters, or by cutting clots in different lengths. ${ }^{205,212,236}$ Strict control of the molecular and cellular properties of clots could reduce the experimental variability and increase the reproducibility in the investigation of thrombolytic agents. However, spontaneous recanalization or multifocal distal embolization after intra-arterial injection and the circle of Willis anatomy variations could have variable effects on the location and extent of the resulting cerebral infarction.

We previously showed that the heterogeneous nature of a mouse embolic stroke model could be characterized and managed by using a combined approach of in vivo cerebral blood flow (CBF) monitoring and ex vivo near-infrared fluorescent imaging to visualize thrombus. ${ }^{216,217}$ More recently, we developed fibrin-targeted glycol-chitosan-coated gold nanoparticles (GCAuNPs) for computed tomography (CT)-based direct imaging of cerebral thromboembolism and carotid thrombosis. ${ }^{217}$ In a follow-up study, thromboembolic burden and the efficacy of tPA therapy could be assessed serially, noninvasively, and quantitatively using microCT and the fibrin-targeted AuNPs in mice. ${ }^{237}$

\section{In situ thrombosis models}

\section{Thrombin-induced thromboembolic stroke model}

Purified thrombin injection into the lumen of the MCA exposed by excising the dura after performing a small craniotomy leads to in situ thrombosis, followed by CBF reduction and cerebral infarction. ${ }^{230,232,238}$ Thrombi that were produced by this method in Swiss mice consisted mainly of polymerized fibrin containing a low number of platelets. ${ }^{232}$ This composition does not seem to accurately reflect that of clots in human ischemic stroke. Approximately $75 \%$ of the clots retrieved using the Merci device showed platelet/fibrin accumulation, linear neutrophil/monocyte deposition, and erythrocyte-rich accumulation. ${ }^{239}$ However, another study demonstrated a highly complex ultrastructure of human clots with a diverse organization of fibrin, platelets, and RBCs within each thrombus and across various thrombi. ${ }^{240}$ Injecting $\mathrm{FeCl}_{3}$ instead of thrombin could generate platelet-rich cerebral thrombi, providing an opportunity for studying the influence of different clot components on the efficacy of a 
thrombolytic agent. ${ }^{230}$

Mortality rates are lower owing to the less invasive nature of the surgical procedure compared with the intra-arterial clot injection-induced thromboembolic stroke model. In addition, site-specific thrombin injection-mediated accurate and consistent clot localization may ensure more reproducible infarct volumes. However, a study characterizing this model in $\mathrm{C} 57$ black/6J mice $(n=126)$ showed that $65 \%$ of animals $(n=82)$ were excluded because of an unsuitable location of the MCA bifurcation for thrombin injection, bleeding complications, or spontaneous recanalization within 20 minutes $(n=26)$. Only 44 animals demonstrated stable clot formation and cortical infarction. Spontaneous recanalization within 24 hours was observed in non-human primates as well as in mice, ${ }_{1}^{241}$ complicating the analysis and interpretation of the therapeutic efficacy of a thrombolytic agent. Moreover, this model suffers from the difficulty of assessing functional neurological deficits. However, a previous study demonstrated the utility of this model for comparing the efficacy of alteplase on infarct volume at different doses $(0.9,5$, and $10 \mathrm{mg} / \mathrm{kg})$ and at different times after stroke onset (from 20 minutes to 4 hours). At either high (5 to $10 \mathrm{mg} /$ $\mathrm{kg}$ ) or low $(0.9 \mathrm{mg} / \mathrm{kg})$ doses of alteplase, early ( $<3$ hours) treatment significantly reduced the final infarct volume, whereas late administration showed no effect. ${ }^{242}$

\section{$\mathrm{FeCl}_{3}$-induced thromboembolic model}

Thrombosis is induced by topical application of 2.5\% to 35\% ferric chloride $\left(\mathrm{FeCl}_{3}\right)$ to the artery or vein after surgically exposing the target vessel. The generally accepted pathomechanism of $\mathrm{FeCl}_{3}$-induced thrombosis is oxidative vascular wall injury, causing endothelial denudation and in situ thrombosis. As another possible mechanism, ${ }^{243,244}$ micromolar levels of ferrous ions permeate the endothelium, and the ions in the bloodstream form agglomerates with platelets, RBCs, and plasma proteins, which subsequently induces thrombosis. Activated platelets, fibrin strands, and entrapped erythrocytes were found on the endothelial surface of the rat carotid artery 10 minutes after 35\% $\mathrm{FeCl}_{3}$ application. ${ }^{245}$ The clot size, degree of vessel occlusion, and blood flow reduction can be managed by adjusting the concentration and duration of the $\mathrm{FeCl}_{3}$ application. In a later dose-ranging study, ${ }_{1}^{246} 2.5 \% \mathrm{FeCl}_{3}$ applied to the mouse carotid artery for 10 minutes was sufficient to occlude blood flow completely. Topical application of $10 \% \mathrm{FeCl}_{3}$ to the distal MCA for 3 minutes induced thrombus formation, CBF reduction, and ischemia without hemispheric swelling, hemorrhage, or mortality by 24 hours. Because of rapid thrombus formation at a pre-defined location with high reproducibility in the clot size, this model has been widely used for cardiovascular research.
Previously, we developed the first hyperacute direct thrombus imaging technique using CT and thrombus-seeking GC-AuNPs, which enables in vivo assessment of thrombus burden/distribution and characterization of its evolution promptly and quantitatively. ${ }^{247}$ MicroCT imaging could visualize both the presence and extent of thrombi in mouse carotid arteries without a single failure of detection. The AuNP thrombus imaging enabled the monitoring of thrombus evolution (either spontaneous or posttPA), which could be mapped at high resolution in both space and time. A long circulating half-life (up to 3 weeks) of GCAuNPs allowed for repetition or ongoing monitoring of thrombogenesis and thrombolysis without repeated injections of the imaging agent.

\section{Photochemical thrombosis model}

Intravenous injection of a photosensitive dye (e.g., Rose Bengal or erythrosine B) and light illumination to the cortical cerebral artery induces in situ thrombosis, CBF reduction, and cerebral infarction. ${ }^{248-258}$ Light can be illuminated through the thinned skull of the animal brain without craniotomy. Dye-light interaction generates reactive oxygen species that causes endothelial damage and platelet aggregation, leading to the formation of a platelet-rich thrombus at the site of the photochemical reaction.

A recent study using this mode ${ }^{252}$ showed that infarct size was not affected by depletion or functional inhibition of platelets. The authors suggested potential mechanisms, such as blood-brain barrier disruption-mediated parenchymal edema causing secondary vascular compression as well as inflammatory brain damage involving cytotoxic radicals, microglial activation, and cytokine release. ${ }^{259-261}$

The major strengths of the photothrombosis model include reproducible infarct size and location as well as a relatively simple surgical procedure and low operative mortality. The infarct size can be controlled by changing the concentration of Rose Bengal and the duration of light illumination. ${ }^{258,262-269}$

Poor responses to tPA-mediated thrombolytic therapy, which is likely due to a low fibrin content in the platelet-rich clots, was improved by increasing the fibrin content by mixing Rose Bengal $(50 \mathrm{mg} / \mathrm{kg})$ with thrombin $(80 \mathrm{U} / \mathrm{kg}){ }^{270}$

Lu et al. ${ }^{255}$ showed that photochemical thrombotic stroke could be induced in conscious animals. They mounted a wearable miniature headstage, which allows for both light illumination $\left(532 \mathrm{~nm}\right.$ ) to the MCA and laser speckle contrast imaging ${ }^{271}$ on the head of rats. This model better reflects most of the clinical stroke, which does not occur in anesthetic conditions, providing a unique research platform to study stroke pathophysiology without the confounding effects of anesthesia. 


\section{Clinical testing of novel thrombolytics}

Alteplase significantly improves post-stroke functional outcomes; however, potential risks, particularly symptomatic intracranial hemorrhage, can complicate intravenous tPA therapy. ${ }^{2,77,272}$ As described before, TNK compared with alteplase has a higher affinity for fibrin and less impairment of hemostasis. TNK has greater resistance to PAI- 1 and a longer plasma halflife, allowing single intravenous bolus injection. ${ }^{273}$ Desmoteplase is another new thrombolytic agent with a longer half-life and higher fibrin specificity than alteplase. ${ }^{65}$

In the Australian TNK trial, TNK 0.1 and $0.25 \mathrm{mg} / \mathrm{kg}$, compared with alteplase, were associated with better clinical outcomes in 75 patients with large artery occlusion, probably due to higher reperfusion rates and more favorable perfusion patterns within 6 hours from symptom onset. ${ }^{274}$ However, the Tenecteplase versus Alteplase for Management of Acute Ischemic Stroke (NORTEST) study investigators reported no difference between TNK $0.4 \mathrm{mg} / \mathrm{kg}$ and alteplase in terms of the safety and efficacy in 1,100 patients who were eligible for IV thrombolysis within 4.5 hours of onset. ${ }^{275}$ The majority of participants had a mild stroke (median National Institutes of Health Stroke Scale of 4), which complicates the interpretation of the results.

With the advent of endovascular thrombectomy, Extending the Time for Thrombolysis in Emergency Neurological DeficitsIntra-Arterial (EXTEND-IA) TNK trial compared TNK $0.25 \mathrm{mg} / \mathrm{kg}$ with alteplase in patients with large vessel occlusion who were scheduled for thrombectomy. TNK was superior to alteplase in the recanalization on the initial angiogram (22\% vs. 10\%). In addition, TNK achieved a more favorable 90-day functional outcome in the ordinal analysis of the modified Rankin Scale score (common odds ratio, $1.7 ; P=0.037$ ). ${ }^{73}$

Clinical trials of desmoteplase selected patients who came in late time windows but had salvageable tissue on brain imaging. In the Study of DIAS-2 trial, 90 and $125 \mu \mathrm{g} / \mathrm{kg}$ of desmoteplase did not increase the clinical response rates at 90 days compared with the placebo in patients with ischemic stroke within 3 to 9 hours after symptom onset. ${ }^{276}$ The DIAS3 trials involved 492 patients with high-grade stenosis or occlusion of major cerebral arteries within 3 to 9 hours after symptom onset. Desmoteplase $(90 \mu \mathrm{g} / \mathrm{kg})$ and the placebo did not differ significantly in terms of the primary outcome: the proportion of patients with a favorable modified Rankin Scale score (0-2) at 90 days (51\% vs. 50\%, respectively). ${ }^{65}$ The DIAS-4 trial was terminated early, and the combined results of DIAS-3, DIAS-4, and DIAS-J (Japan) were published. ${ }^{277}$ Late treatment with intravenous $90 \mu \mathrm{g} / \mathrm{kg}$ desmoteplase was safe with an increased rate of recanalization, although it did not significantly improve the functional outcome at 3 months. ${ }^{277}$ The limitations of the studies were: (1) focusing on the late time window, (2) without consistent application of imaging criteria for patient selection, and (3) sample size-related issues in DIAS-2 (small sample size) and DIAS-3 (21\% patients excluded from the final analysis).

To date, TNK and desmoteplase are the only drugs that have undergone phase II clinical trials. In terms of safety and efficacy, clinical trials did not definitively prove the superiority of TNK over alteplase. ${ }^{73,272-275,278,279}$ A meta-analysis demonstrated a similar rate of symptomatic intracerebral hemorrhage (sICH) between TNK (3\%) and alteplase (3\%). ${ }^{280}$ Although two trials (Australian TNK and EXTEND-IA TNK) have proven the superior efficacy of TNK over alteplase, the meta-analysis did not show the overall superiority of TNK. Ongoing large sample-sized trials (Alteplase-Tenecteplase Trial Evaluation for Stroke Thrombolysis [NCT02814409] and Tenecteplase versus Alteplase for Stroke Thrombolysis Evaluation TASTE-2 [ACTRN12613000243718]) comparing the safety and efficacy of TNK versus alteplase may provide more conclusive data. ${ }^{273}$ Previous studies suggest that desmoteplase and alteplase might have comparable safety and efficacy, although a head-to-head study has not been conducted.

As described above, in the Australian TNK and EXTEND-IA TNK trials, TNK achieved a higher recanalization rate compared with alteplase. ${ }^{274}$ In TNK-tPA Evaluation for Minor Ischemic Stroke With Proven Occlusion (TEMPO-1) trial, TNK demonstrated a remarkable recanalization rate in patients with mild stroke and intracranial arterial occlusion. ${ }^{273}$ Desmoteplase also showed an outstanding recanalization rate in the DIAS-3 trials. ${ }^{65}$ Thus, it is likely that patients with large vessel occlusion due to large or long thrombi may benefit more from recanalization therapy using the new thrombolytics. An ongoing TEMPO-2 trial (NCT02398656) may contribute to this issue.

Although the era of endovascular therapy has finally come, intra-arterial mechanical thrombectomy cannot and will not be performed in all patients with acute ischemic stroke. Intravenous thrombolysis may facilitate subsequent mechanical thrombectomy and can be performed promptly while preparing the intra-arterial intervention. Moreover, the chemical lysis of microthrombi as well as the mechanical recanalization of large arteries is required for optimal cerebral reperfusion, which is crucial for improving clinical outcomes. In addition, in the setting of the drip-and-ship approach, a single bolus injection (of a new thrombolytic drug) will have a clear logistical advantage over the continuous infusion (of tPA). 


\section{Conclusions and perspectives in the development of thrombolytics}

Despite a large variety of biochemical features of natural and engineered thrombolytic enzymes, none have demonstrated "optimal" clinical outcomes. A missing piece of information that will be useful for the development of more efficient thromboIytics is the complete tertiary structures of alteplase, TNK, and desmoteplase. These structures have not been determined so far, and computer models do not provide the necessary molecular details. Particularly, it would be informative to know the structures of their complexes with fibrin and/or plasminogen, which would allow for more effective engineering of the affinity and specificity. We are witnessing improvements in structural techniques, such as cryo-electron microscopy, $\mathrm{X}$-ray crystallography, and nuclear magnetic resonance (NMR) spectroscopy, which can reveal the structures of even large multi-domain and multi-protein complexes.

We see a duality in the current trends in the development of novel thrombolytics. On the one hand, novel thrombolytics are being developed using more precise design strategies. Research and developmental strategies in this field have moved from deleting and fusing whole domains of proteins to introducing point mutations. Researchers are increasingly using the methods of rational protein design, which are more specific, focused, and reliable. On the other hand, the vastly expanding repertoire of deoxyribonucleic acid sequences and small molecules enables the discovery of novel thrombolytics in biological samples collected from living ecosystems. We envision that future thrombolytic formulations can be developed by (1) computational rational design that is based on new structures identified by protein crystallography, NMR spectroscopy, and cryo-electron microscopy; (2) discovering novel thrombolytics using databases of protein sequences and small molecules; (3) combining with antioxidants or neuroprotective drugs that could potentially attenuate reperfusion injury, and (4) improving the delivery of thrombolytics via liposomes or other nanocarriers.

One of the attractive strategies for improving thrombolytic treatment is the use of sonothrombolysis. ${ }^{281}$ To test newly designed thrombolytics under these specific conditions, progressive and reliable in vitro methodologies combining standard assays and ultrasound devices are being developed. ${ }^{282-285}$ At the same time, the development of advanced in vitro microfluidic models simulating real arterial events are of large interest. ${ }^{286-292}$ Thanks to peristaltic pumps circulating blood inside microfluidic chips with blood vessel-like channels coated with endothelial cells, the in vitro testing is becoming highly reliable and relevant to clinical practice. ${ }^{286,289-291}$ Once it is confirmed that these assays provide robust results, this approach might represent an effective and ethical alternative to animal testing. Moreover, substituting animal blood with human blood in the microfluidic system could lead to even more relevant results. The development and use of such advanced methods are crucial for the production and robust screening of newly discovered or rationally engineered thrombolytic proteins.

Clinical research has been based mainly on the use of a single thrombolytic agent, but precisely defined cocktails of multiple drugs might have better joint effects for thrombolytic therapy. The most effective combinations should be explored in vitro and in vivo using realistic animal models. ${ }^{293}$ Finally, we would like to underline the critical importance of clinical trials; their unbiased performance is crucial for effective decision-making.

\section{Disclosure}

The authors have no financial conflicts of interest.

\section{Acknowledgments}

The authors would like to express their thanks to the Czech Ministry of Education for financial support (CZ.02.1.01/0.0/0.0/1 6_026/0008451). Dmitri Nikitin is the recipient of an individual grant MSCA fellowship (CZ.02.2.69/0.0/0.0/19_074/0016274), and Martin Toul is supported by the scholarship Brno Ph.D. Talent. Dong-Eog Kim is supported by grants from the Global Research Laboratory program (NRF-2015K1A1A2028228) and Basic Science Research program (NRF-2020R1A2C3008295), and Seungbum Choi from the Basic Science Research program (NRF-2019R1C1C1002909), funded by the Korean government. The authors also thank Su-Kyoung Lee for improving the figures and Dr. Jung E. Park for critical revision of this paper.

\section{References}

1. GBD 2016 Stroke Collaborators. Global, regional, and national burden of stroke, 1990-2016: a systematic analysis for the Global Burden of Disease Study 2016. Lancet Neurol 2019;18:439-458.

2. Hacke W, Kaste M, Bluhmki E, Brozman M, Dávalos A, Gui-

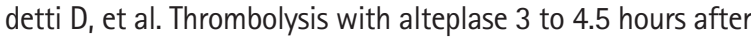
acute ischemic stroke. N Engl J Med 2008;359:1317-1329.

3. Jovin TG, Chamorro $A$, Cobo $E$, de Miquel MA, Molina CA, Rovira $A$, et al. Thrombectomy within 8 hours after symptom onset in ischemic stroke. N Engl J Med 2015;372:2296-2306.

4. Goyal M, Demchuk AM, Menon BK, Eesa M, Rempel JL, Thornton $J$, et al. Randomized assessment of rapid endovascular 
treatment of ischemic stroke. N Engl J Med 2015;372:10191030.

5. Albers GW, Marks MP, Kemp S, Christensen S, Tsai JP, Ortega-Gutierrez $S$, et al. Thrombectomy for stroke at 6 to 16 hours with selection by perfusion imaging. $N$ Engl J Med 2018;378:708-718.

6. Aguiar de Sousa D, von Martial R, Abilleira S, Gattringer T, Kobayashi A, Gallofré $M$, et al. Access to and delivery of acute ischaemic stroke treatments: a survey of national scientific societies and stroke experts in 44 European countries. Eur Stroke J 2019;4:13-28.

7. Kim JS. tPA helpers in the treatment of acute ischemic stroke: are they ready for clinical use? J Stroke 2019;21:160174.

8. Rijken DC, Wijngaards G, Zaal-de Jong M, Welbergen J. Purification and partial characterization of plasminogen activator from human uterine tissue. Biochim Biophys Acta 1979;580:140-153.

9. Rijken DC, Hoylaerts M, Collen D. Fibrinolytic properties of one-chain and two-chain human extrinsic (tissue-type) plasminogen activator. J Biol Chem 1982;257:2920-2925.

10. Angles-Cano $E_{1}$ Balaton $A$, Le Bonniec B, Genot $E_{1}$ Elion J, Sultan Y. Production of monoclonal antibodies to the high fibrin-affinity, tissue-type plasminogen activator of human plasma: demonstration of its endothelial origin by immunolocalization. Blood 1985;66:913-920.

11. Correa F, Gauberti M, Parcq J, Macrez R, Hommet $Y$, Obiang $P$, et al. Tissue plasminogen activator prevents white matter damage following stroke. J Exp Med 2011;208:1229-1242.

12. Louessard M, Lacroix A, Martineau M, Mondielli G, Montagne $A$, Lesept $F$, et al. Tissue plasminogen activator expression is restricted to subsets of excitatory pyramidal glutamatergic neurons. Mol Neurobiol 2016;53:5000-5012.

13. Ny T, Elgh F, Lund B. The structure of the human tissue-type plasminogen activator gene: correlation of intron and exon structures to functional and structural domains. Proc Natl Acad Sci U SA 1984;81:5355-5359.

14. Lijnen HR, Collen D. Strategies for the improvement of thrombolytic agents. Thromb Haemost 1991;66:88-110.

15. Gething MJ, Adler B, Boose JA, Gerard RD, Madison EL, McGookey $D$, et al. Variants of human tissue-type plasminogen activator that lack specific structural domains of the heavy chain. EMBO J 1988;7:2731-2740.

16. Collen D, Lijnen HR. Tissue-type plasminogen activator: a historical perspective and personal account. J Thromb Haemost 2004;2:541-546.

17. Lucore CL, Fry ET, Nachowiak DA, Sobel BE. Biochemical determinants of clearance of tissue-type plasminogen activa- tor from the circulation. Circulation 1988;77:906-914.

18. Bakhit $C$, Lewis D, Billings $R$, Malfroy B. Cellular catabolism of recombinant tissue-type plasminogen activator. Identification and characterization of a novel high affinity uptake system on rat hepatocytes. J Biol Chem 1987;262:87168720.

19. Pennica D, Holmes WE, Kohr WJ, Harkins RN, Vehar GA, Ward CA, et al. Cloning and expression of human tissue-type plasminogen activator cDNA in E. coli. Nature 1983;301:214-221.

20. Baranes D, Lederfein D, Huang YY, Chen M, Bailey CH, Kandel ER. Tissue plasminogen activator contributes to the late phase of LTP and to synaptic growth in the hippocampal mossy fiber pathway. Neuron 1998;21:813-825.

21. Lee SH, Ko HM, Kwon KJ, Lee J, Han SH, Han DW, et al. tPA regulates neurite outgrowth by phosphorylation of LRP5/6 in neural progenitor cells. Mol Neurobiol 2014;49:199-215.

22. Nicole 0 , Docagne F, Ali C, Margaill I, Carmeliet P, MacKenzie ET, et al. The proteolytic activity of tissue-plasminogen activator enhances NMDA receptor-mediated signaling. Nat Med 2001;7:59-64.

23. Pang PT, Teng HK, Zaitsev E, Woo NT, Sakata K, Zhen S, et al. Cleavage of proBDNF by tPA/plasmin is essential for longterm hippocampal plasticity. Science 2004;306:487-491.

24. Pawlak R, Magarinos AM, Melchor J, McEwen B, Strickland $\mathrm{S}$. Tissue plasminogen activator in the amygdala is critical for stress-induced anxiety-like behavior. Nat Neurosci 2003;6:168-174.

25. Seeds NW, Basham ME, Haffke SP. Neuronal migration is retarded in mice lacking the tissue plasminogen activator gene. Proc Natl Acad Sci U S A 1999;96:14118-14123.

26. Su EJ, Fredriksson L, Schielke GP, Eriksson U, Lawrence DA. Tissue plasminogen activator-mediated PDGF signaling and neurovascular coupling in stroke. J Thromb Haemost 2009;7 Suppl 1:155-158.

27. Sila CA, Furlan AJ. Therapy for acute ischemic stroke: the door opens: interpreting the NINDS rt-PA stroke study. Cleve Clin J Med 1996;63:77-79.

28. Emberson J, Lees KR, Lyden P, Blackwell L, Albers G, Bluhmki $E_{1}$ et al. Effect of treatment delay, age, and stroke severity on the effects of intravenous thrombolysis with alteplase for acute ischaemic stroke: a meta-analysis of individual patient data from randomised trials. Lancet 2014;384:19291935.

29. Suzuki S, Saito M, Suzuki N, Kato H, Nagaoka N, Yoshitake $\mathrm{S}$, et al. Thrombolytic properties of a novel modified human tissue-type plasminogen activator (E6010): a bolus injection of E6010 has equivalent potency of lysing young and aged 
canine coronary thrombi. J Cardiovasc Pharmacol 1991; 17:738-746.

30. den Heijer P, Vermeer F, Ambrosioni E, Sadowski Z, LópezSendón $J \mathrm{~L}$, von Essen $\mathrm{R}$, et al. Evaluation of a weight-adjusted single-bolus plasminogen activator in patients with myocardial infarction: a double-blind, randomized angiographic trial of lanoteplase versus alteplase. Circulation 1998;98: 2117-2125.

31. Ishikawa A, Ohata T, Imamura K, Iwasaki M, Sakai T, Matsuzawa $T$, et al. Single and repeated intravenous toxicity studies of pamiteplase (genetical recombination) in rats and monkeys. J Toxicol Sci 1997;22:117-133.

32. Agnelli G, Pascucci C, Nenci GG, Mele A, Bürgi R, Heim J. Thrombolytic and haemorrhagic effects of bolus doses of tissue-type plasminogen activator and a hybrid plasminogen activator with prolonged plasma half-life (K2tu-PA: CGP 42935). Thromb Haemost 1993;70:294-300.

33. Narita M, Bu G, Herz J, Schwartz AL. Two receptor systems are involved in the plasma clearance of tissue-type plasminogen activator (t-PA) in vivo. J Clin Invest 1995;96:11641168.

34. Kuiper J, Van't Hof A, Otter M, Biessen EA, Rijken DC, van Berkel TJ. Interaction of mutants of tissue-type plasminogen activator with liver cells: effect of domain deletions. Biochem J 1996;313:775-780.

35. Rathore YS, Rehan M, Pandey K, Sahni G, Ashish. First structural model of full-length human tissue-plasminogen activator: a SAXS data-based modeling study. J Phys Chem B 2012;116:496-502.

36. Mican J, Toul M, Bednar D, Damborsky J. Structural biology and protein engineering of thrombolytics. Comput Struct Biotechnol J 2019;17:917-938.

37. Keyt BA, Paoni NF, Refino CJ, Berleau L, Nguyen $H$, Chow A, et al. A faster-acting and more potent form of tissue plasminogen activator. Proc Natl Acad Sci U S A 1994;91:36703674.

38. Campbell BC, Mitchell PJ, Churilov L, Yassi N, Kleinig TJ, Yan $B$, et al. Tenecteplase versus alteplase before endovascular thrombectomy (EXTEND-IA TNK): a multicenter, randomized, controlled study. Int J Stroke 2018;13:328-334.

39. Macfarlane RG, Pilling J. Fibrinolytic activity of normal urine. Nature 1947;159:779.

40. Gibson PR, van de Pol E, Doe WF. Cell associated urokinase activity and colonic epithelial cells in health and disease. Gut 1991;32:191-195.

41. Helenius MA, Saramäki OR, Linja MJ, Tammela TL, Visakorpi T. Amplification of urokinase gene in prostate cancer. Cancer Res 2001;61:5340-5344.
42. Kusch A, Tkachuk S, Lutter S, Haller H, Dietz R, Lipp M, et al. Monocyte-expressed urokinase regulates human vascular smooth muscle cell migration in a coculture model. Biol Chem 2002;383:217-221.

43. Medcalf RL, Hamilton JA. Human synovial fibroblasts produce urokinase-type plasminogen activator. Arthritis Rheum 1986;29:1397-1401.

44. Sidenius N, Blasi F. The urokinase plasminogen activator system in cancer: recent advances and implication for prognosis and therapy. Cancer Metastasis Rev 2003;22:205-222.

45. Roychoudhury PK, Khaparde SS, Mattiasson B, Kumar A. Synthesis, regulation and production of urokinase using mammalian cell culture: a comprehensive review. Biotechnol Adv 2006;24:514-528.

46. Collen D, Lijnen HR, Vanlinthout I, Kieckens L, Nelles L, Stassen JM. Thrombolytic and pharmacokinetic properties of human tissue-type plasminogen activator variants, obtained by deletion and/or duplication of structural/functional domains, in a hamster pulmonary embolism model. Thromb Haemost 1991;65:174-180.

47. Kadir RRA, Bayraktutan U. Urokinase plasminogen activator: a potential thrombolytic agent for ischaemic stroke. Cell Mol Neurobiol 2020;40:347-355.

48. Bell WR, Simon TL, Stengle JM, Sherry S. The urokinase-streptokinase pulmonary embolism trial (phase II) results. Circulation 1974;50:1070-1071.

49. Spiecker M, Windeler J, Vermeer F, Michels R, Seabra-Gomes $\mathrm{R}$, vom Dahl J, et al. Thrombolysis with saruplase versus streptokinase in acute myocardial infarction: five-year results of the PRIMI trial. Am Heart J 1999;138:518-524.

50. Bär FW, Meyer J, Vermeer F, Michels R, Charbonnier B, Haerten $K_{1}$ et al. Comparison of saruplase and alteplase in acute myocardial infarction. SESAM Study Group. The Study in Europe with Saruplase and Alteplase in Myocardial Infarction. Am J Cardiol 1997;79:727-732.

51. Tillett WS, Garner RL. The fibrinolytic activity of hemolytic streptococci. J Exp Med 1933;58:485-502.

52. Sun $H$, Ringdahl U, Homeister JW, Fay WP, Engleberg NC, Yang AY, et al. Plasminogen is a critical host pathogenicity factor for group A streptococcal infection. Science 2004; 305:1283-1286.

53. Lack CH. Staphylokinase; an activator of plasma protease. Nature 1948;161:559.

54. Collen D. Staphylokinase: a potent, uniquely fibrin-selective thrombolytic agent. Nat Med 1998;4:279-284.

55. Sakharov DV, Lijnen HR, Rijken DC. Interactions between staphylokinase, plasmin(ogen), and fibrin. Staphylokinase discriminates between free plasminogen and plasminogen bound 
to partially degraded fibrin. J Biol Chem 1996;271:2791227918.

56. Armstrong PW, Burton J, Pakola S, Molhoek PG, Betriu A, Tendera $\mathrm{M}$, et al. Collaborative angiographic patency trial of recombinant staphylokinase (CAPTORS II). Am Heart J 2003;146:484-488.

57. Armstrong PW, Burton JR, Palisaitis D, Thompson CR, Van de Werf $F$, Rose $B$, et al. Collaborative angiographic patency trial of recombinant staphylokinase (CAPTORS). Am Heart $J$ 2000;139:820-823.

58. Cartwright T. The plasminogen activator of vampire bat saliva. Blood 1974;43:317-326.

59. Krätzschmar J, Haendler $B$, Langer $G$, Boidol W, Bringmann $P$, Alagon $A$, et al. The plasminogen activator family from the salivary gland of the vampire bat Desmodus rotundus: cloning and expression. Gene 1991;105:229-237.

60. Bringmann $P$, Gruber D, Liese A, Toschi L, Krätzchmar J, Schleuning WD, et al. Structural features mediating fibrin selectivity of vampire bat plasminogen activators. J Biol Chem 1995;270:25596-25603.

61. Kazemali M, Majidzadeh AK, Sardari S, Saadatirad AH, Khalaj $\mathrm{V}_{\text {, Zarei }} \mathrm{N}$, et al. Design of a novel chimeric tissue plasminogen activator with favorable vampire bat plasminogen activator properties. Enzyme Microb Technol 2014;67:82-86.

62. Saadatirad A, Sardari S, Kazemali M, Zarei N, Davami F, Barkhordari $F$, et al. Expression of a novel chimeric-truncated tPA in Pichia pastoris with improved biochemical properties. $\mathrm{Mol}$ Biotechnol 2014;56:1143-1150.

63. Hacke W, Albers G, Al-Rawi Y, Bogousslavsky J, Davalos A, Eliasziw $M$, et al. The desmoteplase in acute ischemic stroke trial (DIAS): a phase II MRI-based 9-hour window acute stroke thrombolysis trial with intravenous desmoteplase. Stroke 2005;36:66-73.

64. Furlan AJ, Eyding D, Albers GW, Al-Rawi Y, Lees KR, Rowley $H A$, et al. Dose escalation of desmoteplase for acute ischemic stroke (DEDAS): evidence of safety and efficacy 3 to 9 hours after stroke onset. Stroke 2006;37:1227-1231.

65. Albers GW, von Kummer R, Truelsen $T$, Jensen JK, Ravn GM, Grønning BA, et al. Safety and efficacy of desmoteplase given 3-9 $\mathrm{h}$ after ischaemic stroke in patients with occlusion or high-grade stenosis in major cerebral arteries (DIAS-3): a double-blind, randomised, placebo-controlled phase 3 trial. Lancet Neurol 2015;14:575-584.

66. Van de Werf FJ. The ideal fibrinolytic: can drug design improve clinical results? Eur Heart J 1999;20:1452-1458.

67. Tennant SN, Dixon J, Venable TC, Page HL Jr, Roach A, Kaiser $A B$, et al. Intracoronary thrombolysis in patients with acute myocardial infarction: comparison of the efficacy of uroki- nase with streptokinase. Circulation 1984;69:756-760.

68. Marini C, Di Ricco G, Rossi G, Rindi M, Palla R, Giuntini C. Fibrinolytic effects of urokinase and heparin in acute pulmonary embolism: a randomized clinical trial. Respiration 1988;54:162-173.

69. Van Hulle F, Bonkain F, De Clerck D, Aerden D, Vanwijn I, Tielemans $\mathrm{C}$, et al. Efficacy of urokinase lock to treat thrombotic dysfunction of tunneled hemodialysis catheters: a retrospective cohort study. J Vasc Access 2019;20:60-69.

70. Hoylaerts M, Rijken DC, Lijnen HR, Collen D. Kinetics of the activation of plasminogen by human tissue plasminogen activator. Role of fibrin. J Biol Chem 1982;257:2912-2919.

71. Urano T, Castellino FJ, Suzuki Y. Regulation of plasminogen activation on cell surfaces and fibrin. J Thromb Haemost 2018;16:1487-1497.

72. Collen $D$, Lijnen HR. The tissue-type plasminogen activator story. Arterioscler Thromb Vasc Biol 2009;29:1151-1155.

73. Campbell BCV, Mitchell PJ, Churilov L, Yassi N, Kleinig TJ, Dowling RJ, et al. Tenecteplase versus alteplase before thrombectomy for ischemic stroke. N Engl J Med 2018;378: 1573-1582.

74. Bhatia R, Hill MD, Shobha N, Menon B, Bal S, Kochar P, et al. Low rates of acute recanalization with intravenous recombinant tissue plasminogen activator in ischemic stroke: real-world experience and a call for action. Stroke 2010;41: 2254-2258.

75. Bivard A, Huang $X$, Levi CR, Spratt N, Campbell BCV, Cheripelli $B K$, et al. Tenecteplase in ischemic stroke offers improved recanalization: analysis of 2 trials. Neurology 2017;89:62-67.

76. Yaghi S, Willey JZ, Cucchiara B, Goldstein JN, Gonzales NR, Khatri $\mathrm{P}$, et al. Treatment and outcome of hemorrhagic transformation after intravenous alteplase in acute ischemic stroke: a scientific statement for healthcare professionals from the American Heart Association/American Stroke Association. Stroke 2017;48:e343-e361.

77. National Institute of Neurological Disorders and Stroke rtPA Stroke Study Group. Tissue plasminogen activator for acute ischemic stroke. N Engl J Med 1995;333:1581-1587.

78. Mair G, von Kummer R, Adami A, White PM, Adams ME, Yan $B$, et al. Arterial obstruction on computed tomographic or magnetic resonance angiography and response to intravenous thrombolytics in ischemic stroke. Stroke 2017;48:353360.

79. Riedel $\mathrm{CH}$, Zimmermann $P$, Jensen-Kondering $U$, Stingele $R$, Deuschl G, Jansen 0 . The importance of size: successful recanalization by intravenous thrombolysis in acute anterior stroke depends on thrombus length. Stroke 2011:42:1775- 
1777.

80. Menon BK, Al-Ajlan FS, Najm M, Puig J, Castellanos M, Dowlatshahi $D$, et al. Association of clinical, imaging, and thrombus characteristics with recanalization of visible intracranial occlusion in patients with acute ischemic stroke. JAMA 2018;320:1017-1026.

81. Zhang Y, Gladysheva IP, Houng AK, Reed GL. Streptococcus uberis plasminogen activator (SUPA) activates human plasminogen through novel species-specific and fibrin-targeted mechanisms. J Biol Chem 2012;287:19171-19176.

82. Hu Y, Yu D, Wang Z, Hou J, Tyagi R, Liang Y, et al. Purification and characterization of a novel, highly potent fibrinolytic enzyme from Bacillus subtilis DC27 screened from Douchi, a traditional Chinese fermented soybean food. Sci Rep 2019:9:9235.

83. Khursade PS, Galande SH, Shiva Krishna P, Prakasham RS. Stenotrophomonas maltophilia Gd2: a potential and novel isolate for fibrinolytic enzyme production. Saudi J Biol Sci 2019;26:1567-1575.

84. Chen H, McGowan EM, Ren N, Lal S, Nassif N, Shad-Kaneez $F_{\text {, et }}$ al. Nattokinase: a promising alternative in prevention and treatment of cardiovascular diseases. Biomark Insights 2018;13:1177271918785130.

85. Silva PEDCE, Barros RC, Albuquerque WWC, Brandão RMP, Bezerra RP, Porto ALF. In vitro thrombolytic activity of a purified fibrinolytic enzyme from Chlorella vulgaris. J Chromatogr B Analyt Technol Biomed Life Sci 2018;1092:524529.

86. He J, Chen S, Gu J. Identification and characterization of Harobin, a novel fibrino(geno)lytic serine protease from a sea snake (Lapemis hardwickii). FEBS Lett 2007;581:29652973.

87. Li Z, Chen $X$, Guo S, Zhang H, Dong H, Wu G, et al. Engineering of Harobin for enhanced fibrinolytic activity obtained by random and site-directed mutagenesis. Protein Expr Purif 2017;129:162-172.

88. Kim HJ, Shim KH, Yeon SJ, Shin HS. A novel thrombolytic and anticoagulant serine protease from Polychaeta, Diopatra sugokai. J Microbiol Biotechnol 2018;28:275-283.

89. Vanacek $P$, Sebestova E, Babkova P, Bidmanova S, Daniel L, Dvorak $\mathrm{P}$, et al. Exploration of enzyme diversity by integrating bioinformatics with expression analysis and biochemical characterization. ACS Catal 2018;8:2402-2412.

90. Suzuki E, Nishimura N, Yoshikawa T, Kunikiyo $Y$, Hasegawa K, Hasumi K. Efficacy of SMTP-7, a small-molecule anti-inflammatory thrombolytic, in embolic stroke in monkeys. Pharmacol Res Perspect 2018;6:e00448.

91. van Zonneveld AJ, Veerman H, Pannekoek H. Autonomous functions of structural domains on human tissue-type plasminogen activator. Proc Natl Acad Sci U S A 1986;83:46704674.

92. Medcalf RL. Fibrinolysis: from blood to the brain. J Thromb Haemost 2017;15:2089-2098.

93. Niego B, Freeman R, Puschmann TB, Turnley AM, Medcalf RL. t-PA-specific modulation of a human blood-brain barrier model involves plasmin-mediated activation of the Rho kinase pathway in astrocytes. Blood 2012;119:4752-4761.

94. Thiebaut AM, Gauberti M, Ali C, Martinez De Lizarrondo S, Vivien $D$, Yepes $M$, et al. The role of plasminogen activators in stroke treatment: fibrinolysis and beyond. Lancet Neurol 2018;17:1121-1132.

95. Horn IR, van den Berg BM, Moestrup SK, Pannekoek $H$, van Zonneveld AJ. Plasminogen activator inhibitor 1 contains a cryptic high affinity receptor binding site that is exposed upon complex formation with tissue-type plasminogen activator. Thromb Haemost 1998;80:822-828.

96. Cole ES, Nichols EH, Poisson L, Harnois ML, Livingston DJ. In vivo clearance of tissue plasminogen activator: the complex role of sites of glycosylation and level of sialylation. Fibrinolysis 1993;7:15-22.

97. Mohammadi E, Seyedhosseini-Ghaheh H, Mahnam K, Jahanian-Najafabadi A, Sadeghi HMM. Reteplase: structure, function, and production. Adv Biomed Res 2019;8:19.

98. Maheshwari N, Kantipudi S, Maheshwari A, Arora K, Vandana, Kwatra $N$, et al. Amino-terminal fusion of epidermal growth factor 4,5,6 domains of human thrombomodulin on streptokinase confers anti-reocclusion characteristics along with plasmin-mediated clot specificity. PLoS One 2016; $11: \mathrm{e} 0150315$.

99. Taheri MN, Behzad-Behbahani A, Rafiei Dehbidi G, Salehi S, Sharifzadeh S. Engineering, expression and purification of a chimeric fibrin-specific streptokinase. Protein Expr Purif 2016;128:14-21.

100. He J, Di J, Xu R, Zhao B. Novel recombinant thrombolytic and antithrombotic staphylokinase variants with an RGD motif at their N-termini. Biotechnol Appl Biochem 2008; 50:17-23.

101. Szemraj J, Walkowiak B, Kawecka I, Janiszewska G, Buczko W, Bartkowiak J, et al. A new recombinant thrombolytic and antithrombotic agent with higher fibrin affinity: a staphylokinase variant. I. In vitro study. J Thromb Haemost 2005;3:2156-2165.

102. Chiou JF, Woon MD, Cheng SN, Hsu CH, Cherng SC, Hsieh FK, et al. Staphylokinase-annexin XI chimera exhibited efficient in vitro thrombolytic activities. Biosci Biotechnol Biochem 2007;71:1122-1129. 
103. Faraji $H$, Ramezani $M$, Mashkani $B$, Sadeghnia $H R$, Benhangi HM, Hosseini Teshnizi S, et al. Comparison of expression optimization of new derivative of staphylokinase (SAK-2RGDTII) with the rSAK. Biotechnol Prog 2019;35:e2819.

104. Wu SC, Castellino FJ, Wong SL. A fast-acting, modular-structured staphylokinase fusion with kringle-1 from human plasminogen as the fibrin-targeting domain offers improved clot lysis efficacy. J Biol Chem 2003;278:1819918206.

105. Raigani M, Rouini MR, Golabchifar AA, Mirabzadeh E, Vaziri $B$, Barkhordari F, et al. Scale up and pharmacokinetic study of a novel mutated chimeric tissue plasminogen activator (mt-PA) in rats. Sci Rep 2017;7:43028.

106. Davami F, Sardari S, Majidzadeh AK, Hemayatkar $M$, Barkhrdari F, Omidi $\mathrm{M}$, et al. Expression of a novel chimeric truncated t-PA in $\mathrm{CHO}$ cells based on in silico experiments. J Biomed Biotechnol 2010;2010:108159.

107. Bonnard T, Tennant $Z$, Niego B, Kanojia R, Alt $K$, Jagdale $S$, et al. Novel thrombolytic drug based on thrombin cleavable microplasminogen coupled to a single-chain antibody specific for activated GPIIb/IIla. J Am Heart Assoc 2017;6:e004535.

108. Wu XC, Ye R, Duan Y, Wong SL. Engineering of plasmin-resistant forms of streptokinase and their production in Bacillus subtilis: streptokinase with longer functional half-life. Appl Environ Microbiol 1998;64:824-829.

109. Babbal A, Mohanty S, Khasa YP. Engineering of deglycosylated and plasmin resistant variants of recombinant streptokinase in Pichia pastoris. Appl Microbiol Biotechnol 2018;102:10561-10577.

110. Sawhney P, Katare K, Sahni G. PEGylation of truncated streptokinase leads to formulation of a useful drug with ameliorated attributes. PLoS One 2016;11:e0155831.

111. Xu Y, Shi Y, Zhou J, Yang W, Bai L, Wang S, et al. Structure-based antigenic epitope and PEGylation improve the efficacy of staphylokinase. Microb Cell Fact 2017;16:197.

112. Collen D. Engineered staphylokinase variants with reduced immunogenicity. Fibrinolysis Proteolysis 1998;12 Suppl 2:59-65.

113. Thomas GR, Thibodeaux H, Errett CJ, Badillo JM, Keyt BA, Refino CJ, et al. A long-half-life and fibrin-specific form of tissue plasminogen activator in rabbit models of embolic stroke and peripheral bleeding. Stroke 1994;25:2072-2078

114. Armstead WM, Riley J, Yarovoi S, Cines DB, Smith DH, Higazi AA. tPA-S481A prevents neurotoxicity of endogenous tPA in traumatic brain injury. J Neurotrauma 2012;29:17941802.

115. Goulay R, Naveau M, Gaberel T, Vivien D, Parcq J. Optimized tPA: a non-neurotoxic fibrinolytic agent for the drainage of intracerebral hemorrhages. J Cereb Blood Flow Metab 2018;38:1180-1189.

116. Gurewich V, Pannell R, Simmons-Byrd A, Sarmientos P, Liu JN, Badylak SF. Thrombolysis vs. bleeding from hemostatic sites by a prourokinase mutant compared with tissue plasminogen activator. J Thromb Haemost 2006;4:1559-1565.

117. Koudelka S, Mikulik R, Masek J, Raska M, Turanek Knotigova $P$, Miller $A D$, et al. Liposomal nanocarriers for plasminogen activators. J Control Release 2016;227:45-57.

118. Bruch GE, Fernandes LF, Bassi BLT, Alves MTR, Pereira IO, Frezard F, et al. Liposomes for drug delivery in stroke. Brain Res Bull 2019;152:246-256.

119. Kim JY, Kim JK, Park JS, Byun Y, Kim CK. The use of PEGylated liposomes to prolong circulation lifetimes of tissue plasminogen activator. Biomaterials 2009;30:5751-5756.

120. Al-Ahmady ZS, Jasim D, Ahmad SS, Wong R, Haley M, Coutts $\mathrm{G}$, et al. Selective liposomal transport through blood brain barrier disruption in ischemic stroke reveals two distinct therapeutic opportunities. ACS Nano 2019;13:1247012486.

121. Partoazar A, Nasoohi $S$, Rezayat SM, Gilani $K$, Mehr SE, Amani $A$, et al. Nanoliposome containing cyclosporine $A$ reduced neuroinflammation responses and improved neurological activities in cerebral ischemia/reperfusion in rat. Fundam Clin Pharmacol 2017;31:185-193.

122. Tiebosch IA, Crielaard BJ, Bouts MJ, Zwartbol R, Salas-Perdomo A, Lammers T, et al. Combined treatment with recombinant tissue plasminogen activator and dexamethasone phosphate-containing liposomes improves neurological outcome and restricts lesion progression after embolic stroke in rats. J Neurochem 2012;123:65-74.

123. Absar S, Gupta N, Nahar K, Ahsan F. Engineering of plasminogen activators for targeting to thrombus and heightening thrombolytic efficacy. J Thromb Haemost 2015;13:15451556.

124. Zhang N, Li C, Zhou D, Ding C, Jin Y, Tian Q, et al. Cyclic RGD functionalized liposomes encapsulating urokinase for thrombolysis. Acta Biomater 2018;70:227-236.

125. Laing ST, Moody M, Smulevitz B, Kim H, Kee P, Huang S, et al. Ultrasound-enhanced thrombolytic effect of tissue plasminogen activator-loaded echogenic liposomes in an in vivo rabbit aorta thrombus model-brief report. Arterioscler Thromb Vasc Biol 2011;31:1357-1359.

126. Korin N, Gounis MJ, Wakhloo AK, Ingber DE. Targeted drug delivery to flow-obstructed blood vessels using mechanically activated nanotherapeutics. JAMA Neurol 2015; 72:119-122.

127. Saxena $V$, Gacchina Johnson $C$, Negussie $A H$, Sharma KV, 
Dreher MR, Wood BJ. Temperature-sensitive liposome-mediated delivery of thrombolytic agents. Int J Hyperthermia 2015;31:67-73.

128. Xu J, Zhang $Y, X u$ J, Liu G, Di C, Zhao $X$, et al. Engineered nanoplatelets for targeted delivery of plasminogen activators to reverse thrombus in multiple mouse thrombosis models. Adv Mater 2020;32:e1905145.

129. Chen $K$, Wang $Y$, Liang $H$, Xia $S$, Liang $W$, Kong J, et al. Intrinsic biotaxi solution based on blood cell membrane cloaking enables fullerenol thrombolysis in vivo. ACS Appl Mater Interfaces 2020;12:14958-14970.

130. Wang $X$, Lin $X_{1}$ Loy JA, Tang J, Zhang XC. Crystal structure of the catalytic domain of human plasmin complexed with streptokinase. Science 1998;281:1662-1665.

131. Rehan M, Sagar A, Sharma V, Mishra S, Ashish, Sahni G. Penta-I-lysine potentiates fibrin-independent activity of human tissue plasminogen activator. J Phys Chem B. 2015; 119:13271-13277.

132. Ghaheh HS, Ganjalikhany MR, Yaghmaei P, Pourfarzam M, Sadeghi HMM. Improving the solubility, activity, and stability of reteplase using in silico design of new variants. Research in pharmaceutical sciences 2019;14:359-368.

133. Krishnamurthy A, Belur PD, Subramanya SB. Methods available to assess therapeutic potential of fibrinolytic enzymes of microbial origin: a review. J Anal Sci Technol 2018;9:10.

134. Kotb E. Activity assessment of microbial fibrinolytic enzymes. Appl Microbiol Biotechnol 2013;97:6647-6665.

135. Millar WT, Smith JF. A highly sensitive solid phase assay for plasminogen activators using $125 \mathrm{l}$-fibrinogen. Thromb Res 1978;13:389-395.

136. Millar WT, Smith JF. The comparison of solid phase and fibrin plate methods for the measurement of plasminogen activators. Thromb Res 1983;30:431-439

137. Hume M. Radioactive (1125) human plasma clots for assay of thrombolytic activity. J Lab Clin Med 1964;63:699-702.

138. Moroz LA, Gilmore NJ. A rapid and sensitive 125I-fibrin solid-phase fibrinolytic assay for plasmin. Blood 1975;46:543553.

139. Loskutoff DJ. Effect of thrombin on the fibrinolytic activity of cultured bovine endothelial cells. J Clin Invest 1979; 64:329-332.

140. Roche PC, Campeau JD, Shaw ST. A rapid and highly sensitive solid-phase radioassay for plasminogen activators. Thromb Res 1983;31:269-277.

141. Gidron E, Margalit R, Shalitin Y. A rapid screening test for reduced fibrinolytic activity of plasma: streptokinase activated lysis time. J Clin Pathol 1978;31:54-57.

142. Patchett SE, Enright $H_{1}$ Afdhal N, O'Connell W, O'Donoghue
DP. Clot lysis by gastric juice: an in vitro study. Gut 1989; 30:1704-1707.

143. Goldenberg NA, Hathaway WE, Jacobson L, Manco-Johnson M. A new global assay of coagulation and fibrinolysis. $J$ Thromb Res 2005;116:345-356.

144. Astrup T, Mullertz S. The fibrin plate method for estimating fibrinolytic activity. Arch Biochem Biophys 1952;40:346-351.

145. Jespersen J, Astrup T. A study of the fibrin plate assay of fibrinolytic agents. Optimal conditions, reproducibility and precision. Haemostasis 1983;13:301-315.

146. Marsh NA, Gaffney PJ. The rapid fibrin plate: a method for plasminogen activator assay. J Thromb Haemost 1977; 38:545-551.

147. Lassen M. Heat denaturation of plasminogen in the fibrin plate method. Acta Physiol Scand 1953;27:371-376.

148. Barta G. Dyed fibrin plate assay of fibrinolysis. Can J Physiol Pharmacol 1966;44:233-240.

149. Fossum S, Hoem NO. Urokinase and non-urokinase fibrinolytic activity in protease-inhibitor-deprived plasma, assayed by a fibrin micro-plate method. Immunopharmacology 1996;32:119-121.

150. Sherry S, Alkjaersig N, Fletcher AP. Activity of plasmin and streptokinase-activator on substituted arginine and lysine esters. Thromb Diath Haemorrh 1966;16:18-31.

151. Niinobe M, Hitomi Y, Fujii S. A sensitive colorimetric assay for various proteases using naphthyl ester derivatives as substrates. J Biochem 1980;87:779-783.

152. Barlow GH, Marder VJ. Plasma urokinase levels measured by chromogenic assay after infusions of tissue culture or urinary source material. Thromb Res 1980;18:431-437.

153. Kulseth MA, Helgeland L. A highly sensitive chromogenic microplate assay for quantification of rat and human plasminogen. Anal Biochem 1993;210:314-317.

154. Nieuwenhuizen W, Wijngaards G, Groeneveld E. Fluorogenic substrates for sensitive and differential estimation of urokinase and tissue plasminogen activator. Haemostasis 1978;7:146-149.

155. Zimmerman M. Direct fluorescent assay of urokinase and plasminogen activators of normal and malignant cells: kinetics and inhibitor profiles. Proc Natl Acad Sci U S A 1978;75:750-753.

156. Mander P, Cho SS, Simkhada JR, Choi YH, Yoo JC. A low molecular weight chymotrypsin-like novel fibrinolytic enzyme from Streptomyces sp. CS624. Process Biochem 2011;46:1449-1455.

157. Salazar AM, Rodriguez-Acosta A, Girón ME, Aguilar I, Guerrero $B$. A comparative analysis of the clotting and fibrinoIytic activities of the snake venom (Bothrops atrox) from 
different geographical areas in Venezuela. Thromb Res 2007;120:95-104.

158. Stewart RJ. Identification of the mechanism responsible for the increased fibrin specificity of TNK-tissue plasminogen activator relative to tissue plasminogen activator. J Biol Chem 2000;275:10112-10120.

159. Radcliffe $R$, Heinze T. Stimulation of tissue plasminogen activator by denatured proteins and fibrin clots: a possible additional role for plasminogen activator? Arch Biochem Biophys 1981;211:750-761.

160. Longstaff $C$, Whitton CM. A proposed reference method for plasminogen activators that enables calculation of enzyme activities in SI units. Thromb Haemost 2004; 2:1416-1421.

161. Stewart RJ, Fredenburgh JC, Weitz JI. Characterization of the interactions of plasminogen and tissue and vampire bat plasminogen activators with fibrinogen, fibrin, and the complex of d-Dimer noncovalently linked to fragment E. J Biol Chem 1998;273:18292-18299.

162. Hawkey CM, Stafford JL. A standard clot method for the assay of plasminogen activators, anti-activators, and plasmin. J Clin Pathol 1964;17:175-181.

163. Somerville DA. A technique for demonstrating fibrinolysis by cutaneous bacteria. J Clin Pathol 1972;25:740-741.

164. Chakrabarti R, Fearnley GR. The 'fibrinolytic potential' as a simple measure of spontaneous fibrinolysis. J Clin Pathol 1962;15:228-230.

165. Blix S. The effectiveness of activators in clot lysis, with special reference to fibrinolytic therapy: a new method for determination of preformed clot lysis. Acta Med Scand Suppl 1962;386:1-24.

166. Howell M. A method for assessing clot lysis. J Clin Pathol 1964;17:310-312.

167. Prasad S, Kashyap RS, Deopujari JY, Purohit HJ, Taori GM, Daginawala HF. Development of an in vitro model to study clot lysis activity of thrombolytic drugs. Thromb J 2006;4:14.

168. Narasimhan MK, Chandrasekaran M, Rajesh M. Fibrinolytic enzyme production by newly isolated Bacillus cereus SRM001 with enhanced in-vitro blood clot lysis potential. J Gen Appl Microbiol 2015;61:157-164.

169. Smith $A A$, Jacobson $\amalg$, Miller BI, Hathaway WE, Manco-Johnson M. A new euglobulin clot lysis assay for global fibrinolysis. J Thromb Res 2003;112:329-337.

170. He S, Bremme K, Blombäck M. A laboratory method for determination of overall haemostatic potential in plasma. I. Method design and preliminary results. Thromb Res 1999;96:145-156.

171. Ilich A. Development and application of global assays of hyper- and hypofibrinolysis. Res Pract Thromb Haemost
2020;4:46-53.

172. Zamanlu M, Eskandani M, Mohammadian R, Entekhabi $N$, Rafi M, Farhoudi M. Spectrophotometric analysis of thrombolytic activity: SATA assay. Bioimpacts 2018;8:31-38.

173. Bonnard T, Law LS, Tennant Z, Hagemeyer CE. Development and validation of a high throughput whole blood thrombolysis plate assay. Sci Rep 2017;7:2346.

174. Donahue SM, Otto CM. Thromboelastography: a tool for measuring hypercoagulability, hypocoagulability, and fibrinoIysis. J Vet Emerg Crit Care 2005;15:9-16.

175. Bolliger D, Seeberger MD, Tanaka KA. Principles and practice of thromboelastography in clinical coagulation management and transfusion practice. Transfus Med Rev 2012;26:1-13.

176. Fan NK, Keegan PM, Platt MO, Averett RD. Experimental and imaging techniques for examining fibrin clot structures in normal and diseased states. J Vis Exp 2015;98:e52019.

177. Kim DE, Kim JY, Lee SK, Ryu JH, Kwon IC, Ahn CH, et al. Combined near-infrared fluorescent imaging and $\mathrm{mi}-$ cro-computed tomography for directly visualizing cerebral thromboemboli. J Vis Exp 2016;54294.

178. Davami F, Sardari S, Majidzadeh AK, Hemayatkar M, Barkhordari $F$, Enayati $S$, et al. A novel variant of t-PA resistant to plasminogen activator inhibitor-1: expression in $\mathrm{CHO}$ cells based on in silico experiments. BMB Rep 2011;44:34-39.

179. Hekman CM, Loskutoff DJ. Kinetic analysis of the interactions between plasminogen activator inhibitor 1 and both urokinase and tissue plasminogen activator. Arch Biochem Biophys 1988;262:199-210.

180. Chmielewska J, Rånby $M$, Wiman B. Evidence for a rapid inhibitor to tissue plasminogen activator in plasma. Thromb Res 1983;31:427-436.

181. Franke AE, Danley DE, Kaczmarek FS, Hawrylik SJ, Gerard $R D$, Lee $S E$, et al. Expression of human plasminogen activator inhibitor type-1 (PAl-1) in Escherichia coli as a soluble protein comprised of active and latent forms. Isolation and crystallization of latent PAI-1. Biochim Biophys Acta 1990;1037:16-23.

182. Wind $T$, Jensen MA, Andreasen PA. Epitope mapping for four monoclonal antibodies against human plasminogen activator inhibitor type-1: implications for antibody-mediated PAI-1-neutralization and vitronectin-binding. Eur J Biochem 2001;268:1095-1106.

183. Yakovlev S, Makogonenko E, Kurochkina N, Nieuwenhuizen W, Ingham K, Medved L. Conversion of fibrinogen to fibrin:mechanism of exposure of tPA- and plasminogen-binding sites. Biochemistry 2000;39:15730-15741.

184. Tsurupa G, Medved L. Identification and characterization of novel tPA- and plasminogen-binding sites within fibrin(o- 
gen) alpha C-domains. Biochemistry 2001;40:801-808.

185. Kim PY, Tieu LD, Stafford AR, Fredenburgh JC, Weitz JI. A high affinity interaction of plasminogen with fibrin is not essential for efficient activation by tissue plasminogen activator. J Biol Chem 2012;287:4652-4661.

186. Tsurupa G, Medved L. Fibrinogen alpha $\mathrm{C}$ domains contain cryptic plasminogen and tPA binding sites. Ann N Y Acad Sci 2001;936:328-330.

187. de Munk GA, Caspers MP, Chang GT, Pouwels PH, Enger-Valk $\mathrm{BE}$, Verheijen $\mathrm{JH}$. Binding of tissue-type plasminogen activator to lysine, lysine analogues, and fibrin fragments. Biochemistry 1989;28:7318-7325.

188. Jiao J, Yu M, Ru B. Characterization of a recombinant chimeric plasminogen activator with enhanced fibrin binding. Enzymology 2001;1546:399-405.

189. Higgins DL, Vehar GA. Interaction of one-chain and twochain tissue plasminogen activator with intact and plasmin-degraded fibrin. Biochemistry 1987;26:7786-7791.

190. Verheijen JH, Caspers MP, Chang GT, de Munk GA, Pouwels $\mathrm{PH}$, Enger-Valk BE. Involvement of finger domain and kringle 2 domain of tissue-type plasminogen activator in fibrin binding and stimulation of activity by fibrin. EMBO J 1986; 5:3525-3530.

191. Xu Z, Balsara RD, Gorlatova NV, Lawrence DA, Castellino FJ, Ploplis VA. Conservation of critical functional domains in murine plasminogen activator inhibitor-1. J Biol Chem 2004;279:17914-17920.

192. Andersen OM, Petersen HH, Jacobsen C, Moestrup SK, Etzerodt $\mathrm{M}$, Andreasen $\mathrm{PA}$, et al. Analysis of a two-domain binding site for the urokinase-type plasminogen activator-plasminogen activator inhibitor-1 complex in low-density-lipoprotein-receptor-related protein. Biochem J 2001; 357:289-296.

193. Sánchez MC, Chiabrando GA, Vides MA. Pregnancy zone protein-tissue-type plasminogen activator complexes bind to low-density lipoprotein receptor-related protein (LRP). Arch Biochem Biophys 2001;389:218-222.

194. Dolmer K, Campos A, Gettins PG. Quantitative dissection of the binding contributions of ligand lysines of the receptor-associated protein (RAP) to the low density lipoprotein receptor-related protein (LRP1). J Biol Chem 2013;288: 24081-24090.

195. Jensen JK, Dolmer K, Schar C, Gettins PGW. Receptor-associated protein (RAP) has two high-affinity binding sites for the low-density lipoprotein receptor-related protein (LRP): consequences for the chaperone functions of RAP. Biochem J 2009;421:273-282.

196. Asahi M, Rammohan R, Sumii T, Wang X, Pauw RJ, Weissig
V, et al. Antiactin-targeted immunoliposomes ameliorate tissue plasminogen activator-induced hemorrhage after focal embolic stroke. J Cereb Blood Flow Metab 2003;23:895899.

197. Esmaeeli-Nadimi A, Kennedy D, Allahtavakoli M. Opening the window: ischemic postconditioning reduces the hyperemic response of delayed tissue plasminogen activator and extends its therapeutic time window in an embolic stroke model. Eur J Pharmacol 2015;764:55-62.

198. Hao CH, Ding WX, Sun O, Li XX, Wang WT, Zhao ZY, et al. Thrombolysis with rhPro-UK 3 to 6 hours after embolic stroke in rat. Neurol Res 2019;41:1034-1042.

199. Ishrat $T$, Fouda AY, Pillai B, Eldahshan W, Ahmed H, Waller $J L_{\text {, et }}$ al. Dose-response, therapeutic time-window and tPA-combinatorial efficacy of compound 21: a randomized, blinded preclinical trial in a rat model of thromboembolic stroke. J Cereb Blood Flow Metab 2019;39:1635-1647.

200. Jin R, Xiao AY, Liu S, Wang M, Li G. Taurine reduces tPA (tissue-type plasminogen activator)-induced hemorrhage and microvascular thrombosis after embolic stroke in rat. Stroke 2018;49:1708-1718.

201. Jin R, Zhu X, Li G. Embolic middle cerebral artery occlusion (MCAO) for ischemic stroke with homologous blood clots in rats. J Vis Exp 2014;91:51956.

202. Kudo M, Aoyama A, Ichimori S, Fukunaga N. An animal model of cerebral infarction. Homologous blood clot emboli in rats. Stroke 1982;13:505-508.

203. Lee KY, Bae ON, Weinstock S, Kassab M, Majid A. Neuroprotective effect of asiatic acid in rat model of focal embolic stroke. Biol Pharm Bull 2014;37:1397-1401.

204. Lehmann J, Hartig W, Seidel A, Fuldner C, Hobohm C, Grosche $J$, et al. Inflammatory cell recruitment after experimental thromboembolic stroke in rats. Neuroscience 2014; 279:139-154.

205. Ren M, Lin Z, Qian H, Choudhury GR, Liu R, Liu H, et al. Embolic middle cerebral artery occlusion model using thrombin and fibrinogen composed clots in rat. J Neurosci Methods 2012;211:296-304.

206. Shimamura N, Matsuda N, Kakuta K, Narita A, Ohkuma H. A model of rat embolic cerebral infarction with a quantifiable, autologous arterial blood clot. Trans/ Stroke Res 2013;4:564570.

207. Si Z, Liu J, Hu K, Lin Y, Liu J, Wang A. Effects of thrombolysis within 6 hours on acute cerebral infarction in an improved rat embolic middle cerebral artery occlusion model for ischaemic stroke. J Cell Mol Med 2019;23:2468-2474.

208. Takano K, Carano RA, Tatlisumak T, Meiler M, Sotak CH, Kleinert HD, et al. Efficacy of intra-arterial and intravenous 
prourokinase in an embolic stroke model evaluated by diffusion-perfusion magnetic resonance imaging. Neurology 1998;50:870-875.

209. Zhang L, Chopp M, Jia L, Cui Y, Lu M, Zhang ZG. Atorvastatin extends the therapeutic window for tPA to $6 \mathrm{~h}$ after the onset of embolic stroke in rats. J Cereb Blood Flow Metab 2009;29:1816-1824.

210. Zhang L, Chopp M, Lu M, Zhang T, Li C, Winter S, et al. Demonstration of therapeutic window of cerebrolysin in embolic stroke: a prospective, randomized, blinded, and placebo-controlled study. Int J Stroke 2017;12:628-635.

211. Zhang L, Chopp M, Meier DH, Winter S, Wang L, Szalad A, et al. Sonic hedgehog signaling pathway mediates cerebrolysin-improved neurological function after stroke. Stroke 2013;44:1965-1972.

212. Zhang $L$, Zhang RL, Jiang , Ding G, Chopp M, Zhang ZG. Focal embolic cerebral ischemia in the rat. Nat Protoc 2015;10:539-547.

213. Chen $S$, Chen Z, Cui J, McCrary ML, Song H, Mobashery S, et al. Early abrogation of gelatinase activity extends the time window for tPA thrombolysis after embolic focal cerebral ischemia in mice. eNeuro 2018;5:ENEURO.0391-17.2018.

214. Huang L, Wang J, Huang S, Siaw-Debrah F, Nyanzu M, Zhuge 0 . Polyacrylic acid-coated nanoparticles loaded with recombinant tissue plasminogen activator for the treatment of mice with ischemic stroke. Biochem Biophys Res Commun 2019;516:565-570.

215. Kanazawa M, Kawamura $K$, Takahashi T, Miura M, Tanaka $Y$, Koyama $\mathrm{M}$, et al. Multiple therapeutic effects of progranulin on experimental acute ischaemic stroke. Brain 2015; 138:1932-1948.

216. Kim DE, Kim JY, Nahrendorf M, Lee SK, Ryu JH, Kim K, et al. Direct thrombus imaging as a means to control the variability of mouse embolic infarct models: the role of optical molecular imaging. Stroke 2011;42:3566-3573.

217. Kim JY, Ryu JH, Schellingerhout D, Sun IC, Lee SK, Jeon S, et al. Direct imaging of cerebral thromboemboli using computed tomography and fibrin-targeted gold nanoparticles. Theranostics 2015;5:1098-1114.

218. Sladojevic N, Oh GT, Kim HH, Beaulieu LM, Falet H, Kaminski $\mathrm{K}$, et al. Decreased thromboembolic stroke but not atherosclerosis or vascular remodelling in mice with ROCK2-deficient platelets. Cardiovasc Res 2017; 113:1307-1317.

219. Zhu YQ, Zhao MY, Gu XC, Teng GJ. Evaluation of neurovascular function in mouse cortex using multispectral optical imaging after ischemic stroke. Zhonghua Yi Xue Za Zhi 2019;99:2943-2946.

220. Culp WC, Woods SD, Skinner RD, Brown AT, Lowery JD,
Johnson $\mathrm{JL}$, et al. Dodecafluoropentane emulsion decreases infarct volume in a rabbit ischemic stroke model. J Vasc Interv Radiol 2012;23:116-121.

221. Jahan R, Villablanca JP, Harris RJ, Duarte-Vogel $S$, Williams CK, Vinters HV, et al. Selective middle cerebral artery occlusion in the rabbit: technique and characterization with pathologic findings and multimodal MRI. J Neurosci Methods 2019;313:6-12.

222. Lapchak PA, Araujo DM, Pakola S, Song D, Wei J, Zivin JA. Microplasmin: a novel thrombolytic that improves behavioral outcome after embolic strokes in rabbits. Stroke 2002;33:2279-2284.

223. Lapchak PA, Araujo DM, Song D, Wei J, Purdy R, Zivin JA. Effects of the spin trap agent disodium-[tert-butylimino) methyl]benzene-1,3-disulfonate N-oxide (generic NXY-059) on intracerebral hemorrhage in a rabbit large clot embolic stroke model: combination studies with tissue plasminogen activator. Stroke 2002;33:1665-1670.

224. Lapchak PA, Araujo DM, Song D, Wei J, Zivin JA. Neuroprotective effects of the spin trap agent disodium-[(tert-butylimino)methyl]benzene-1,3-disulfonate $\mathrm{N}$-oxide (generic NXY-059) in a rabbit small clot embolic stroke model: combination studies with the thrombolytic tissue plasminogen activator. Stroke 2002;33:1411-1415.

225. Liu S, Xu X, Cheng O, Zu O, Lu S, Yu J, et al. Simple quantitative measurement based on DWI to objectively judge DWI-FLAIR mismatch in a canine stroke model. Diagn Interv Radiol 2015;21:348-354.

226. Xu XO, Cheng QG, Zu QO, Lu SS, Yu J, Sheng Y, et al. Comparative study of the relative signal intensity on DWI, FLAIR, and $\mathrm{T} 2$ images in identifying the onset time of stroke in an embolic canine model. Neurol Sci 2014;35:1059-1065.

227. Lee IJ, Yang YC, Hsu JW, Chang WT, Chuang YJ, Liau I. Zebrafish model of photochemical thrombosis for translational research and thrombolytic screening in vivo. J Biophotonics 2017;10:494-502.

228. Kito G, Nishimura A, Susumu T, Nagata R, Kuge Y, Yokota C, et al. Experimental thromboembolic stroke in cynomolgus monkey. J Neurosci Methods 2001;105:45-53.

229. Kuge $Y$, Yokota C, Tagaya M, Hasegawa Y, Nishimura A, Kito $\mathrm{G}$, et al. Serial changes in cerebral blood flow and flow-metabolism uncoupling in primates with acute thromboembolic stroke. J Cereb Blood Flow Metab 2001;21:202-210.

230. Ansar S, Chatzikonstantinou E, Wistuba-Schier A, Mirau-Weber S, Fatar M, Hennerici MG, et al. Characterization of a new model of thromboembolic stroke in C57 black/6J mice. Trans/ Stroke Res 2014;5:526-533.

231. Zhang Z, Zhang RL, Jiang $\mathrm{O}$, Raman SB, Cantwell L, Chopp 
M. A new rat model of thrombotic focal cerebral ischemia. J Cereb Blood Flow Metab 1997;17:123-135.

232. Orset $C$, Macrez $R$, Young AR, Panthou D, Angles-Cano $E_{\text {, }}$

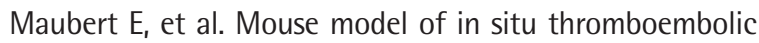
stroke and reperfusion. Stroke 2007;38:2771-2778.

233. Beech JS, Williams SC, Campbell CA, Bath PM, Parsons $A A_{1}$ Hunter $\mathrm{AJ}$, et al. Further characterisation of a thromboembolic model of stroke in the rat. Brain Res 2001;895:18-24.

234. Atochin DN, Murciano JC, Gursoy-Ozdemir Y, Krasik T, Noda

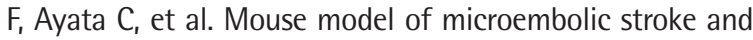
reperfusion. Stroke 2004;35:2177-2182.

235. Agren A, Edgren G, Kardell M, Ostlund A, Wikman AT. In vitro combinations of red blood cell, plasma and platelet components evaluated by thromboelastography. Blood Transfus 2014;12:491-496.

236. Zhang RL, Chopp M, Zhang ZG, Jiang Q, Ewing JR. A rat model of focal embolic cerebral ischemia. Brain Res 1997;766:83-92.

237. Kim DE, Kim JY, Schellingerhout D, Ryu JH, Lee SK, Jeon $S_{\text {, }}$ et al. Quantitative imaging of cerebral thromboemboli in vivo: the effects of tissue-type plasminogen activator. Stroke 2017;48:1376-1385.

238. Chen Y, Zhu W, Zhang W, Libal N, Murphy SJ, Offner $H_{\text {, et }}$ al. A novel mouse model of thromboembolic stroke. J Neurosci Methods 2015;256:203-211.

239. Smith WS, Sung G, Starkman S, Saver JL, Kidwell CS, Gobin YP, et al. Safety and efficacy of mechanical embolectomy in acute ischemic stroke: results of the $\mathrm{MERCl}$ trial. Stroke 2005;36:1432-1438.

240. Mehta BP, Nogueira RG. Should clot composition affect choice of endovascular therapy? Neurology 2012;79:S6367.

241. Gauberti M, Martinez de Lizarrondo S, Orset C, Vivien D. Lack of secondary microthrombosis after thrombin-induced stroke in mice and non-human primates. J Thromb Haemost 2014;12:409-414.

242. Orset C, Haelewyn B, Allan SM, Ansar S, Campos F, Cho TH, et al. Efficacy of alteplase in a mouse model of acute ischemic stroke: a retrospective pooled analysis. Stroke 2016;47: 1312-1318

243. Tseng MT, Dozier A, Haribabu B, Graham UM. Transendothelial migration of ferric ion in $\mathrm{FeCl} 3$ injured murine common carotid artery. Thromb Res 2006;118:275-280.

244. Ciciliano JC, Sakurai Y, Myers DR, Fay ME, Hechler B, Meeks $\mathrm{S}$, et al. Resolving the multifaceted mechanisms of the ferric chloride thrombosis model using an interdisciplinary microfluidic approach. Blood 2015;126:817-824.

245. Kurz KD, Main BW, Sandusky GE. Rat model of arterial thrombosis induced by ferric chloride. Thromb Res 1990;60: 269-280.

246. Karatas H, Erdener SE, Gursoy-Ozdemir Y, Gurer G, Soylemezoglu F, Dunn AK, et al. Thrombotic distal middle cerebral artery occlusion produced by topical $\mathrm{FeCl}(3)$ application: a novel model suitable for intravital microscopy and thrombolysis studies. J Cereb Blood Flow Metab 2011;31: 1452-1460.

247. Kim DE, Kim JY, Sun IC, Schellingerhout D, Lee SK, Ahn CH, et al. Hyperacute direct thrombus imaging using computed tomography and gold nanoparticles. Ann Neurol 2013;73: 617-625.

248. Dietrich WD, Ginsberg MD, Busto R, Watson BD. Photochemically induced cortical infarction in the rat. 1. Time course of hemodynamic consequences. J Cereb Blood Flow Metab 1986;6:184-194.

249. Hilger T, Blunk JA, Hoehn M, Mies G, Wester P. Characterization of a novel chronic photothrombotic ring stroke model in rats by magnetic resonance imaging, biochemical imaging, and histology. J Cereb Blood Flow Metab 2004;24:789-797.

250. Hu X, Wester P, Brannstrom T, Watson BD, Gu W. Progressive and reproducible focal cortical ischemia with or without late spontaneous reperfusion generated by a ring-shaped, laser-driven photothrombotic lesion in rats. Brain Res Brain Res Protoc 2001;7:76-85.

251. Kim HS, Kim D, Kim RG, Kim JM, Chung E, Neto PR, et al. A rat model of photothrombotic capsular infarct with a marked motor deficit: a behavioral, histologic, and microPET study. J Cereb Blood Flow Metab 2014;34:683-689.

252. Kleinschnitz $C$, Braeuninger $S$, Pham M, Austinat M, Nölte I, Renné $T$, et al. Blocking of platelets or intrinsic coagulation pathway-driven thrombosis does not prevent cerebral infarctions induced by photothrombosis. Stroke 2008;39:12621268.

253. Kuroiwa T, Xi G, Hua Y, Nagaraja TN, Fenstermacher JD, Keep RF. Development of a rat model of photothrombotic ischemia and infarction within the caudoputamen. Stroke 2009; 40:248-253.

254. Lee VM, Burdett NG, Carpenter A, Hall LD, Pambakian PS, Patel $S$, et al. Evolution of photochemically induced focal cerebral ischemia in the rat: magnetic resonance imaging and histology. Stroke 1996;27:2110-2118

255. Lu H, Li Y, Yuan L, Li H, Lu X, Tong S. Induction and imaging of photothrombotic stroke in conscious and freely moving rats. J Biomed Opt 2014;19:96013.

256. Provenzale JM, Jahan R, Naidich TP, Fox AJ. Assessment of the patient with hyperacute stroke: imaging and therapy. Radiology 2003;229:347-359. 
257. Qian C, Li PC, Jiao Y, Yao HH, Chen YC, Yang J, et al. Precise characterization of the penumbra revealed by MRI: a modified photothrombotic stroke model study. PLoS One 2016; $11: \mathrm{e} 0153756$.

258. Watson BD, Dietrich WD, Busto R, Wachtel MS, Ginsberg MD. Induction of reproducible brain infarction by photochemically initiated thrombosis. Ann Neurol 1985;17:497504.

259. Schroeter $M$, Jander $S$, Stoll G. Non-invasive induction of focal cerebral ischemia in mice by photothrombosis of cortical microvessels: characterization of inflammatory responses. J Neurosci Methods 2002;117:43-49.

260. Kleinschnitz C, Bendszus M, Frank M, Solymosi L, Toyka KV, Stoll $G$. In vivo monitoring of macrophage infiltration in experimental ischemic brain lesions by magnetic resonance imaging. J Cereb Blood Flow Metab 2003;23:1356-1361.

261. Jander S, Schroeter M, Stoll G. Role of NMDA receptor signaling in the regulation of inflammatory gene expression after focal brain ischemia. J Neuroimmunol 2000;109:181187.

262. Jolkkonen J, Jokivarsi K, Laitinen T, Grohn O. Subacute hemorrhage and resolution of edema in Rose Bengal stroke model in rats coincides with improved sensorimotor functions. Neurosci Lett 2007;428:99-102.

263. Moon SK, Alaverdashvili M, Cross AR, Whishaw IQ. Both compensation and recovery of skilled reaching following small photothrombotic stroke to motor cortex in the rat. Exp Neurol 2009;218:145-153.

264. Pevsner PH, Eichenbaum JW, Miller DC, Pivawer G, Eichenbaum KD, Stern A, et al. A photothrombotic model of small early ischemic infarcts in the rat brain with histologic and MRI correlation. J Pharmacol Toxicol Methods 2001;45:227233.

265. Pierpaoli C, Righini A, Linfante I, Tao-Cheng JH, Alger JR, Di Chiro G. Histopathologic correlates of abnormal water diffusion in cerebral ischemia: diffusion-weighted MR imaging and light and electron microscopic study. Radiology 1993; 189:439-448.

266. Schroeter M, Franke C, Stoll G, Hoehn M. Dynamic changes of magnetic resonance imaging abnormalities in relation to inflammation and glial responses after photothrombotic cerebral infarction in the rat brain. Acta Neuropathol 2001; 101:114-122.

267. van Bruggen $N$, Cullen BM, King MD, Doran M, Williams SR, Gadian DG, et al. T2- and diffusion-weighted magnetic resonance imaging of a focal ischemic lesion in rat brain. Stroke 1992;23:576-582.

268. Harrison TC, Silasi G, Boyd JD, Murphy TH. Displacement of sensory maps and disorganization of motor cortex after targeted stroke in mice. Stroke 2013;44:2300-2306.

269. Shih AY, Blinder P, Tsai PS, Friedman B, Stanley G, Lyden PD, et al. The smallest stroke: occlusion of one penetrating vessel leads to infarction and a cognitive deficit. Nat Neurosci 2013;16:55-63.

270. Sun YY, Kuo YM, Chen HR, Short-Miller JC, Smucker MR, Kuan CY. A murine photothrombotic stroke model with an increased fibrin content and improved responses to tPA-lytic treatment. Blood Adv 2020;4:1222-1231.

271. Miao P, Lu H, Liu Q, Li Y, Tong S. Laser speckle contrast imaging of cerebral blood flow in freely moving animals. $J$ Biomed Opt 2011;16:090502.

272. IST-3 collaborative group, Sandercock P, Wardlaw JM, Lindley RI, Dennis M, Cohen G, et al. The benefits and harms of intravenous thrombolysis with recombinant tissue plasminogen activator within $6 \mathrm{~h}$ of acute ischaemic stroke (the third international stroke trial [IST-3]): a randomised controlled trial. Lancet 2012;379:2352-2363.

273. Coutts SB, Berge $E_{1}$ Campbell BC, Muir KW, Parsons MW. Tenecteplase for the treatment of acute ischemic stroke: a review of completed and ongoing randomized controlled trials. Int J Stroke 2018;13:885-892.

274. Parsons M, Spratt N, Bivard A, Campbell B, Chung K, Miteff $F$, et al. A randomized trial of tenecteplase versus alteplase for acute ischemic stroke. N Engl J Med 2012;366:1099-1107.

275. Logallo N, Novotny V, Assmus J, Kvistad CE, Alteheld L, Rønning $\mathrm{OM}$, et al. Tenecteplase versus alteplase for management of acute ischaemic stroke (NOR-TEST): a phase 3, randomised, open-label, blinded endpoint trial. Lancet Neurol 2017;16:781-788.

276. Hacke W, Furlan AJ, Al-Rawi Y, Davalos A, Fiebach JB, Gru-

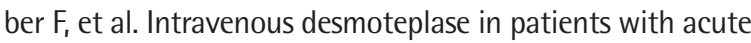
ischaemic stroke selected by MRI perfusion-diffusion weighted imaging or perfusion CT (DIAS-2): a prospective, randomised, double-blind, placebo-controlled study. Lancet Neurol 2009;8:141-150.

277. von Kummer R, Mori $E_{1}$ Truelsen $T$, Jensen JS, Grønning BA, Fiebach JB, et al. Desmoteplase 3 to 9 hours after major artery occlusion stroke: the DIAS-4 trial (efficacy and safety study of desmoteplase to treat acute ischemic stroke). Stroke 2016;47:2880-2887.

278. Hill MD, Michel P. Tenecteplase knocking on the door. Stroke 2018;49:2276-2277.

279. Huang $X$, Maclsaac $R$, Thompson JL, Levin B, Buchsbaum $R$, Haley EC Jr, et al. Tenecteplase versus alteplase in stroke thrombolysis: an individual patient data meta-analysis of randomized controlled trials. Int J Stroke 2016;11:534-543. 
280. Burgos AM, Saver JL. Evidence that tenecteplase is noninferior to alteplase for acute ischemic stroke: meta-analysis of 5 randomized trials. Stroke 2019;50:2156-2162.

281. Alexandrov AV, Molina CA, Grotta JC, Garami Z, Ford SR, Alvarez-Sabin J, et al. Ultrasound-enhanced systemic thrombolysis for acute ischemic stroke. N Engl J Med 2004;351:21702178.

282. Salman-Kesner N, Zaltsman MM, Ertracht O, Atar S. In-vitro assessment of the thrombolytic efficacy of therapeutic ultrasound. Thromb Res 2019;178:63-68.

283. Papadopoulos N, Kyriacou PA, Damianou C. Review of protocols used in ultrasound thrombolysis. J Stroke Cerebrovasc Dis 2017;26:2447-2469.

284. Bader KB, Bouchoux G, Holland CK. Sonothrombolysis. Adv Exp Med Biol 2016;880:339-362.

285. Wang Z. An in vitro assay for sonothrombolysis based on the spectrophotometric measurement of clot thickness. J Ultrasound Med 2017;36:681-698.

286. Amar DN, Epshtein $M$, Korin N. Endothelial cell activation in an embolic ischemia-reperfusion injury microfluidic model. Micromachines (Basel) 2019;10:857.

287. Parimalam SS, Badilescu S, Sonenberg N, Bhat R, Packirisamy M. Lab-on-a-chip for the development of pro-/anti-angiogenic nanomedicines to treat brain diseases. Int J Mol Sci 2019;20:6126.
288. Andrzejewska A. Single-cell, high-throughput analysis of cell docking to vessel wall. J Cereb Blood Flow Metab 2019;39:23082320.

289. Griffin MT, Kim D, Ku DN. Shear-induced platelet aggregation: 3D-grayscale microfluidics for repeatable and localized occlusive thrombosis. Biomicrofluidics 2019;13:054106.

290. Loyau S, Ho-Tin-Noé B, Bourrienne MC, Boulaftali Y, Jandrot-Perrus M. Microfluidic modeling of thrombolysis: effect of antiplatelet and anticoagulant agents on tPA (tissue-type plasminogen activator)-induced fibrinolysis. Arterioscler Thromb Vasc Biol 2018;38:2626-2637.

291. Costa PF, Albers HJ, Linssen JEA, Middelkamp HHT, van der Hout $L$, Passier $R$, et al. Mimicking arterial thrombosis in a $3 \mathrm{D}$-printed microfluidic in vitro vascular model based on computed tomography angiography data. Lab Chip 2017;17: 2785-2792.

292. van Duinen V, Zhu D, Ramakers $C$, van Zonneveld AJ, Vulto $P$, Hankemeier T. Perfused 3D angiogenic sprouting in a high-throughput in vitro platform. Angiogenesis 2019;22:157165.

293. Kim J, Jang HJ, Schellingerhout D, Lee SK, Kim H, Kim YD, et al. Short-term cessation of dabigatran causes a paradoxical prothrombotic state. Ann Neurol 2020 Nov 20 [Epub]. https://doi. org/10.1002/ana.25964. 